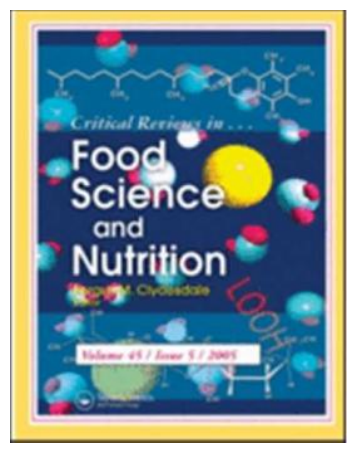

\title{
IMMUNOLOGICAL PROPERTIES OF INULIN-TYPE FRUCTANS
}

\begin{tabular}{|r|l|}
\hline Journal: & Critical Reviews in Food Science and Nutrition \\
\hline Manuscript ID: & BFSN-2011-0511 \\
\hline Manuscript Type: & Review \\
\hline Date Submitted by the Author: & 30-Nov-2011 \\
\hline Complete List of Authors: & Vogt, Leonie; University Medical Center Groningen, Pathology and Medical \\
& Biology \\
& Meyer, Diederick; Sensus B.V., \\
& Pullens, Gerdie; Cosun Food Technology Centre, \\
& Faas, Marijke; University Medical Center Groningen, Pathology and Medical \\
& Biology \\
& Smelt, Maaike; University Medical Center Groningen, Pathology and Medical \\
& Biology \\
& Venema, Koen; TNO Quality of Life, Department of Biosciences \\
& Ramasamy, Uttara; Wageningen University, Laboratory of Food Chemistry \\
& Schols, Henk; Wageningen University, Laboratory of Food Chemistry \\
& De Vos, Paul; University Medical Center Groningen, Pathology and Medical \\
& Biology \\
\hline Keywords: & inulin-type fructans, oligofructose, fructooligosaccharides, prebiotics, gut \\
& associated lymphoid tissue, immunology \\
& \\
\hline
\end{tabular}




\section{IMMUNOLOGICAL PROPERTIES OF INULIN-TYPE FRUCTANS}

Leonie $\operatorname{Vogt}^{1}{ }^{*}$, Diederick Meyer ${ }^{2}$, Gerdie Pullens ${ }^{3}$, Marijke Faas ${ }^{1}$, Maaike Smelt ${ }^{1}$, Koen Venema ${ }^{4}$, Uttara Ramasamy ${ }^{5}$, Henk A. Schols ${ }^{5}$, Paul de Vos ${ }^{1}$

1) Immunoendocrinology, Department of Pathology and Medical Biology, University Medical Center Groningen, Hanzeplein 1, 9700 RB Groningen, The Netherlands

2) Sensus B.V., Borchwerf 3, 4704 RG Roosendaal, The Netherlands

3) Cosun Food Technology Centre, Oostelijke Havendijk 15, 4704 RA, Roosendaal, NL

4) TNO Quality of Life, Department of Biosciences, PO Box 360, 3700 AJ Zeist, The Netherlands

5) Laboratory of Food Chemistry, Wageningen University, PO Box 8129, 6700 EV Wageningen, The Netherlands

* Corresponding author. Tel.: + 31503610109

E-mail: L.M.Vogt@med.umcg.nl

Keywords: Inulin-type fructans, oligofructose, fructooligosaccharide, prebiotics, gut associated lymphoid tissue, immunology 


\section{Critical Reviews in Food Science and Nutrition}

\section{ABSTRACT}

Beneficial effects of inulin-type fructans are discussed in view of studies that applied the oligosaccharides in colon cancer, chronic inflammatory diseases, vaccination efficacy, and prevention of infection and allergy. In the present paper we discuss their immunomodulating effects. It is suggested that immunomodulation is elicited through indirect and direct mechanisms. Indirect mechanisms encompass stimulation of growth and activity of lactic acid bacteria, but can also be caused by fermentation products of these bacteria i.e. short chain fatty acids (SCFAs). Evidence for direct effects on the immune system generally remains to be confirmed. It is suggested that inulin-type fructans can be detected by gut dendritic cells (DCs), through receptor ligation of Pathogen Recognition Receptors (PRRs) such as Toll Like Receptors (TLRs), nucleotide oligomerization domain containing proteins (NODs), C-type lectin receptors (CLRs), and galectins, eventually inducing pro- and anti-inflammatory cytokines. DCs may also exert antigen presenting capacity towards effector cells, such as B cells, T cells, and natural killer (NK) cells locally, or in the spleen. Inulin-type fructans may also ligate PRRs expressed on gut epithelium, which could influence its barrier function. Inulin-type fructans are potent immunomodulating food components that hold many promises for prevention of disease. However, more studies into the mechanisms, dose-effect relations, and structure-function studies are required. 


\section{Critical Reviews in Food Science and Nutrition}

\section{INTRODUCTION}

The scientific and industrial functional food worlds are meeting some new challenges. The consumer awareness that food is not only required to supply energy and nutrition, but also that healthy food is essential for prevention of disease and for both physical and mental well-being (Menrad. 2003,Mollet and Rowland. 2002,Rowland et al. 1998) is growing. This causes an increased demand for functional foods. A category of functional foods that has received much attention in the last decade are products containing prebiotic fibers. Inulin-type fructans belong to this family. Inulin-type fructans are naturally occurring linear plant oligo- and polysaccharides which consist of minimally two fructose-units, and at least one $\beta(2-1)$ fructosyl-fructose glycosydic bond (Kelly. 2008). It is a family of molecules which meet the three classification

criteria for being considered a prebiotic, as defined by Gibson and Roberfroid (Gibson and Roberfroid. 1995); i.e. resistance to hydrolysis or absorption in the upper gastrointestinal (GI) tract, fermentation by the intestinal microbiota, and selective stimulation of the growth and/or activity of beneficial intestinal bacteria, such as Lactobacillus species and Bifidobacterium species. Well-known effects of inulin-type fructans on the gut microbiota are the increase in numbers of these types of bacteria in the intestinal tract, and the selective fermentation of $\beta 2-1$ fructans by most Bifidobacterium species (Gibson et al. 1995), and also by some Lactobacillus species (Kaplan and Hutkins. 2000).

For a considerable period of time, research has mainly focussed on the prebiotic, i.e. indirect effects of inulin-type fructans (Eiwegger et al. 2010,Alles et al. 1996,Roberfroid. 2007,Roberfroid et al. 2010,Delzenne et al. 2007) Somewhat more recent came the notion that prebiotic carbohydrates such as inulin-type fructans may elicit additional direct effects such as 


\section{Critical Reviews in Food Science and Nutrition}

immunomodulation along the gastrointestinal tract (Gibson and Roberfroid. 1995,Eiwegger et al. 2010,Roberfroid et al. 2010,Niess et al. 2005,Hapfelmeier et al. 2008). This may occur via direct contact with gut DCs which sample immune active components from the gut lumen, and intraepithelial lymphocytes (IELs) which can respond upon contact with immune active food components (Hapfelmeier et al. 2008,Chieppa et al. 2006,Murosaki et al. 1999). It is also conceivable that contact of inulin-type fructans with the gut epithelial cells modulates the innate immune barrier by modifying epithelial tight junction integrity, or alters the signals from epithelial cells to the underlying immune cells (Cummings et al. 2001). In addition, the glycosidic and non-glycosidic fermentation products produced by gut microbiota upon fiber supplementation are under investigation for their beneficial health effects as reviewed recently by Meijer et al. (Meijer et al. 2010) and Macfarlane and Macfarlane (Macfarlane and Macfarlane. 2011). The glycosidic fermentation products can be small sized oligosaccharides and the non-glycosidic fermentation products include SCFAs such as acetate, propionate, and butyrate (Kolida et al. 2002,Wong et al. 2006). Although there are some recent reviews on the immunomodulatory properties of inulin-type fructans (Vos et al. 2007b,Seifert and Watzl. 2007,Lomax and Calder. 2009), in the majority of reviews dealing with inulin-type fructans, immunomodulation was mainly discussed as an integral part of the health benefits of prebiotic fibers (Roberfroid et al. 2010,Albers et al. 2005,de Vrese and Schrezenmeir. 2008,Kelly. 2009,Rijnierse et al. 2011). As many studies demonstrate that inulin-type fructans have unique ways for immunomodulation, but the underlying mechanisms are still incompletely understood, we decided to write this review with a focus on the mechanisms of immunoregulatory properties of different types of inulin-type fructans. The present paper provides an overview of the current knowledge of the direct and indirect immunomodulatory properties of inulin-type fructans and 


\section{Critical Reviews in Food Science and Nutrition}

the possible signalling pathways. This will be done in view of the beneficial effects in several diseases including colon cancer, (Delzenne et al. 2007,Forest et al. 2005, Rafter et al. 2007,Rafter

et al. 2007,Reddy et al. 2007), chronic inflammatory diseases (Apanavicius et al. 2007,Lindsay et al. 2006,Casellas et al. 2007,Osman et al. 2006,Ito et al. 2009), vaccination efficacy (Vos et al. 2007a, Vos et al. 2006a, Vos et al. 2006b,Benyacoub et al. 2008,Bunout et al. 2002,Adogony et al. 2007,Saavedra and Tschernia. 2002,Duggan et al. 2003), and prevention of infection and allergy (Eiwegger et al. 2010,Benyacoub et al. 2008,Schouten et al. 2009, van Hoffen et al. 2009,Arslanoglu et al. 2008,Arslanoglu et al. 2007,Perez et al. 2010,Fujitani et al. 2007, Moro et al. 2006a).

\section{Structure and terminology of inulin-type fructans}

Before discussing the immunomodulating properties of inulin-type fructans it is mandatory to discuss the structure and terminology of the family of molecules since their structure or more specifically their chain length probably determines their function in the host. Several studies have indicated that polymer chain length or degree of polymerisation (DP), is an important feature to consider, as it determines where along the GI tract fermentation occurs (Alles et al. 1996,Rumessen et al. 1990,van de Wiele et al. 2007). It appears that short chain fructans are generally fermented relatively fast in the proximal colon, whereas fructans with a relatively long chain resist fermentation until they reach the distal colon where they are metabolized (Roberfroid. 2007,Cummings et al. 2001). In addition, Bifidobacterium species differ along the GI tract, so the different DP can determine the types of bacteria that become enriched. This could render different outcomes in health related parameters (Alles et al. 1996). 


\section{Critical Reviews in Food Science and Nutrition}

Fructans are denoted as Fn, with $\mathrm{F}$ for fructose and $\mathrm{n}$ representing the number of fructose subunits in the polymer. Most inulin-type fructans in nature contain a terminal glucose residue (denoted as a GFn) as biosynthesis starts with sucrose to which fructose residues are added (Kelly. 2008). Figure 1 depicts Haworth projections of these two types of fructans. When the fructan chain starts with a glucose molecule, this glucose can be removed from the chain by hydrolysing sucrase enzymes, which are produced at the tips of the small intestinal epithelial villi (Wu et al. 1992).

Based on chain length, inulin-type fructans are usually rather arbitrarily divided in subcategories with a relatively small (2 to 4), medium (5 to 10) and relatively large chain length (11 to 60 fructose units). Over the course of time the nomenclature to describe inulin-type prebiotics has been inconsistent. Historically, the term fructooligosaccharides or FOS was used for DP 3-5 material derived from sucrose which is thereby only of the GFn type (Carabin and Flamm. 1999). The term oligofructose or OF was used for DP3-10 material derived from native inulin which can be of both the GFn and the Fn type (Roberfroid. 1999). Later, FOS and OF were and are more and more used as synonyms to describe fructans with a chain length ranging between 2 and 10 subunits (Alles et al.1999). To discriminate, the term short chain FOS (scFOS) was used by the company producing this ingredient (Actilight ${ }^{\circledR}$, Eridania-Beghin Say, Belgium), (Bouhnik et al.2007). Some companies use the term long chain FOS (lc-FOS) or OF (lc-OF) for the long chain inulin that is part of a specific galactooligosaccharide (GOS)/inulin mixture. The term inulin is often applied to inulin-type fructans with chain lengths above 10 subunits, however, inulin is the generic term describing all $\beta(2,1)$-fructans without specification of chain length (Kelly. 2008, Roberfroid et al. 2010). In this review we will apply the term FOS for inulin-type fructans of 2 to 10 subunits and we will use the term inulin for inulin-type 


\section{Critical Reviews in Food Science and Nutrition}

fructans with chain lengths above 10 subunits. Chain length is specified where possible to render an overview of the properties of these specific compounds. Figure 3 depicts chain length profiles as an example for a FOS, a FOS-enriched inulin and a high average molecular weight inulin.

\section{The gastrointestinal immune barrier and inulin-type fructans}

Many of the studies addressing immunomodulating effects of inulin-type fructans have focused on the Gut Associated Lymphoid Tissue (GALT, Figure 2). Constituents of this tissue are the lamina propria, Peyer's patches with follicles containing B and T lymphocytes, isolated lymph nodes, mesenteric lymph nodes, and the appendix (Mowat. 2003). Important players in this system are follicle associated Microfold cells (M cells), which are part of the epithelial layer covering the Peyer's patches, and are specialised in transporting antigens from the lumen to the GALT (Ramiro-Puig et al. 2008). DCs and IELs lie in between and just below the epithelial surface. The DCs are capable of sampling and sensing the events in the gut lumen and are strong antigen presenting cells (APCs) (MacPherson et al. 2004). Lamina propria DCs can respond to antigens which have penetrated gut tissue beyond the epithelial barrier and are also strong APCs (MacPherson et al. 2004). Depending on the cytokine environment, APCs can determine whether the $\mathrm{T}$ cells they encounter and present their antigen to, differentiate into regulatory $\mathrm{T}$ lymphocytes (Tr1 or Th3) or into effector (helper) T lymphocytes (Th1, Th2, or Th17) (RamiroPuig et al. 2008). Antigen presentation can occur in the lamina propria or specifically in Peyer's patches or mesenteric lymph nodes (Ramiro-Puig et al. 2008). The immunoglobulin (Ig)M+ B lymphocytes in Peyer's patch follicles are plasma-cell precursors that produce IgA. Memory IgA+ B lymphocytes are generated in the germinal centers of these follicles (Ramiro-Puig et al. 2008,Guilliano et al. 2001,Newberry and Lorenz. 2005). IgA is mainly synthesized in response 


\section{Critical Reviews in Food Science and Nutrition}

to $\mathrm{T}$ lymphocyte activation and the production is again regulated by the cytokine environment. Interleukin (IL)-5, IL-6, and IL-10 stimulate final differentiation of B lymphocytes into $\operatorname{IgA}$ secreting plasma cells (Chin et al. 2003). IgA is the most abundant immunoglobulin in the intestinal mucosa (80-90\%) and forms the first line of defence against colonisation and invasion by pathogens, and against damaging toxins (Trushina et al. 2005). T lymphocyte subtypes can be characterised by the cytokines they produce. Th1 lymphocytes typically secrete Interferon (IFN)$\gamma$, IL-2, and Tumor Necrosis Factor (TNF)- $\beta$, and their main function is phagocyte-mediated defence against viral, bacterial, and protozoic infections. Th2 lymphocytes typically secrete IL-4, IL-5, and IL-13, and act as allergic response mediators and defenders against infections produced by helminths and arthropods (Chin et al. 2003,Brandtzaeg and Johansen. 2005). Although it is becoming clear that the Th1/Th2 model is too simplistic, the Th model has still played an important part in developing our understanding of the roles and behavior of Th cells and the cytokines they produce during an immune response. Therefore, other subtypes to discuss are Th3 cells, Th5 cells, Th9 cells, Th17 cells, and Th22 cells. Th3 cells produce the cytokine Transforming Growth Factor-beta (TGF- $\beta$ ) and IL-10. Both cytokines are inhibitory to Th cells; TGF- $\beta$ suppresses the activity of most of the immune system. Th5 cells constitute a subpopulation of Th cells described by Kurowska-Stolarska et al. (Kurowska-Stolarska et al. 2008). These cells produce mainly IL-5, but not IL-4, both of which are characteristic type 2 cytokines produced by Th2 cells. Recent studies by Veldhoen et al. (Veldhoen et al. 2008) revealed that another Th subset may exist. Th9 cells are claimed to be an IL-9 producing T cell subset focused on defending helminth infections. These cells have been identified as a unique subset of Th cells and constitute a subset of cells known as neutrophil-regulatory T-cells. They are CD4(+) T-cells that are defined by the production of IL-17. Th17 cells develop from naive T- 


\section{Critical Reviews in Food Science and Nutrition}

cells along a pathway that is distinct from the differentiation pathways that give rise to the Th cell populations known as Th1 cells and Th2 cells (Harrington et al. 2005,Harrington et al. 2006). Th22 cells are IL-22-producing cells which coexpress the chemokine receptor CCR6 and the skin-homing receptors CCR4 and CCR10. This subset of IL-22-producing cells is suggested to be important in skin homeostasis and pathology (Trifari et al. 2009). All these different arms of the gastrointestinal immune barrier can be modulated either indirectly, i.e. via microbiota or directly upon consumption of inulin-type fructans.

\section{Indirect mechanism of immunomodulation: Bifidobacteria and SCFAs}

The prebiotic effects of inulin-type fructans are often referred to as bifidogenic effects. These bifidogenic effects were shown in infants (Moro et al. 2006a,Brunser et al. 2006,Kapiki et al. 2007,Kim et al. 2007,Scholtens et al. 2008), adults (Buddington et al. 1996,Bouhnik et al. 1999,Menne et al. 2000,Langlands et al. 2004,Bouhnik et al. 2006), and elderly (Kleessen et al. 1997,Guigoz et al. 2002,Bouhnik et al. 2007). Classically the beneficial effect of inulin-type fructans was assumed to be determined by the effects on the commensal microbiota that formed a barrier for pathogens to enter the host. However, its beneficial effect on commensals probably also has an effect on prevention of inflammation in the systemic circulation. The fermentation products of inulin-type fructans are carbondioxide, hydrogen, lactate, and SCFAs, including acetate, propionate, and butyrate (Kelly. 2008). These products have been studied in relation to beneficial effects and have been reported to protect from colonisation by pathogens or noncommensals by acidification of the colonic content (Alles et al. 1996, Rumessen et al. 1990,Bruhwyler et al. 2008). In addition, they are rapidly adsorbed by the human body (Sembries et al. 2003) and exert their effect on immune cells by binding to activating G protein- 


\section{Critical Reviews in Food Science and Nutrition}

coupled receptors (GPR) (Covington et al. 2006) GPR41 and GPR43 (Covington et al. 2006,Brown et al. 2003,Le Poul et al. 2003). GPR43 is highly expressed in polymorphonuclear cells (PMNs, e.g. neutrophils) and at lower levels in Peripheral Blood Mononuclear Cells (PBMCs) and purified monocytes. GPR41 is similarly expressed in PBMCs but not in PMNs, monocytes and DCs (Le Poul et al. 2003). Both receptors are equally expressed in bone marrow and spleen. The possible immunomodulatory functions of SCFA are highlighted by a recent study in GPR43-/- mice (Maslowski et al. 2009). These mice suffer more from inflammation due to lack of GRP43 binding by SCFA, which normally results in anti-inflammatory effects (Meijer et al. 2010). In these mice, production of inflammatory mediators and immune cell recruitment are increased. These results suggest an immunoregulatory effect for SCFA-mediated GPR43 signalling. More studies are required to confirm whether inulin-type fructan supplementation and subsequent SCFA production actually affects these receptors, but as it has a strong effect on SCFA producing bacteria it is very likely a mechanism by which inulin-type fructans exert their immunomodulatory effect (Stewart et al. 2008).

The intraindividual bifidogenic effect can differ in outcome depending on the initial level of Bifidobacteria, and may also differ between individual Bifidobacterium species (Alles et al. 1996). Although in general this prebiotic effect is present (Kim et al. 2007,Buddington et al. 1996,Bouhnik et al. 1999,Bouhnik et al. 2006,Bouhnik et al. 1996) there are inconsistencies in prebiotic properties of inulin-type fructans throughout literature (Kelly. 2008). These should probably be explained by differences in the applied type i.e. chain length of fructan, the dose, the study population, the duration of supplementation, and the time intervals for microbiological analysis (Kelly. 2008,Brunser et al. 2006,Kim et al. 2007,Bouhnik et al. 1999,Bouhnik et al. 2006). The digestible mono-, and dimers of fructose or glucose which are present in most 


\section{Critical Reviews in Food Science and Nutrition}

prebiotics may also influence the bacterial composition upon supplementation. Minor data are available on possible differences in effects of chain length of inulin-type fructans on prebiotic effects, besides the fact that short chain fructans are fermented by more Bifidobacterium species compared to long chain fructans (Rossi et al. 2005). Future studies addressing the immunological effects of inulin-type fructan supplementation should take into account the microbiota as the composition of the immune system and the microbiota composition are closely related. Therefore future studies should screen broader and also include microbiota analysis and SCFA measurements in order to allow clear interpretation of what are direct and what are indirect effects.

\section{Direct mechanisms of immunomodulation: ligation of PRRs}

To be able to distinguish the good from the bad, the gut immune system is equipped with PRRs. These PRRs recognize molecular structures that are highly conserved and broadly shared by pathogens, known as pathogen-associated molecular patterns (PAMPs) (Janeway. 1989). PRRs include the well-known TLRs, the membrane-bound CLRs, the cytosolic proteins such as NODlike receptors (NLRs) and RIG-I-like receptors (RLRs), and still to be discovered PRRs that mediate sensing of cytosolic DNA or retrovirus infection (Osorio and Reis e Sousa. 2011,Loo and Gale. 2011,Elinav et al. 2011). Upon PAMP recognition, PRRs initiate signaling processes that may lead to cytokine release, inflammation with clearance of the pathogen as a final goal.

Possible direct effects of inulin-type fructans are thought to entail ligation of PRRs on the surface of gut DCs which continuously sample the gut content and are strong APCs (MacPherson et al. 2004). Potential receptors involved are the TLRs (de Kivit et al. 2011). TLRs are involved in epithelial cell proliferation, secretion of $\operatorname{IgA}$ into the gut lumen and expression of 


\section{Critical Reviews in Food Science and Nutrition}

antimicrobial peptides, which are crucial factors for maintaining a healthy epithelial barrier (Abreu. 2010,Hooper and Macpherson. 2010). They are typically known to possess carbohydrate binding properties and upon ligation will instigate several immune responses. For the same reasons, CLRs, NLRs, and galectins are also potentially involved in inulin-type fructan signalling (de Kivit et al. 2011). Besides DCs, many cell types express TLRs, including epithelial cells (Abreu. 2010). It is conceivable that as polysaccharides, inulin-type fructans could ligate TLRs on the gut epithelial cells and thereby modulate barrier function by promoting tight junction stability, similar to the mechanism reported by Karczewski et al. (Karczewski et al. 2010). In addition, the activation of epithelial TLRs could alter their interactions with or signals towards surrounding immune cells such as DCs or IELs (Murosaki et al. 1999). Finally, inulintype fructans may possess the capacity of interacting with cell membrane lipids or even inserting in the membrane (Figdor and van Spriel. 2010). Vereyken et al. (Vereyken et al. 2003a, Vereyken et al. 2003b,Vereyken et al. 2003c) found that there was a chain length-dependent interaction of inulin with lipids. Inulin-type fructans may interact with or even insert into membrane lipid bilayers (Vereyken et al. 2003a,Vereyken et al. 2003b,Vereyken et al. 2003c). This may have a consequence for stimulating events; if insertion renders the membrane more fluid and more dynamic this may facilitate or enhance receptor clustering and subsequent signal transduction.

Notably, this may be more or only relevant for sites where the mucus layer is relatively thin i.e. the small bowel (Johansson et al. 2011), so fructans can reach the cells relatively easily as compared to the large bowel, considering the thickness of the mucus. It should be noted that most hypotheses on direct ligation of inulin-type fructans or their direct contact with epithelial structures remain to be investigated and are at this point still only speculative. 


\section{Critical Reviews in Food Science and Nutrition}

\section{Experimental evidence for immunomodulation}

Many supplementation studies with inulin-type fructans were performed in healthy experimental animal models. Some studies apply inulin-type fructans only in a synbiotic treatment, i.e. in combination with a prebiotic, limiting the possibility to evaluate the actual fructan effects. The features reported most frequently in healthy experimental animals are increased IgA secretion in serum and fecal samples, and increased IL-10 and IFN- $\gamma$ production in two specific structures of the GALT; the mesenteric lymph nodes and the Peyer's patches (Swanson et al. 2002b,Hosono et al. 2003,Nakamura et al. 2004,Roller et al. 2004b) (Table 1). Inconsistency in results are present for IgA in ileum, serum, and feces (Swanson et al. 2002b,Hosono et al. 2003,Nakamura et al. 2004,Kelly- Quagliana et al. 2003,Verlinden et al. 2006). The IgA production was increased or not affected (Swanson et al. 2002b,Hosono et al. 2003,Nakamura et al. 2004,Kelly-Quagliana et al. 2003, Verlinden et al. 2006), the number of lymphocytes in the blood was increased or unaltered (Trushina et al. 2005,Nakamura et al. 2004,Roller et al. 2004b,Shim et al. 2005,Janardhana et al. 2009), and the number of lymphocytes or subsets in the spleen and thymus were increased or unaltered (Rumessen et al. 1990,Trushina et al. 2005,Kapiki et al. 2007,Waligora-Dupriet et al. 2007). In a single study in sea bream, inulin-type fructan supplementation significantly inhibited phagocytosis and respiratory burst in leukocytes (Cerezuela et al. 2008). However, in a study in salmon, supplementation with 7,5\% inulin did not protect against soybean meal-induced colitis (Bakke-McKellep et al. 2007). Evidence for immunomodulation on a genetic level was reported by Yasuda et al.(Yasuda et al. 2009) in a 7 week supplementation study in pigs. Inulin-type fructans were added to the basal corn and soybean meal, which significantly decreased the expression of inflammation related genes, especially in lower gut mucosa These different reports might be attributed to differences in the 


\section{Critical Reviews in Food Science and Nutrition}

administered type of fructan (-mixtures) and other differences in experimental set up such as animal species or feeding protocol (Roberfroid. 2005). More and better designed studies in healthy experimental animals and humans are required to determine the specific immunomodulating effects of different inulin-type fructans. Although inulin-type fructan supplementation studies in healthy adult humans have been performed, immunological parameters were unfortunately often not measured. Immunological effects of inulin-type fructans have been studied in infants and elderly, but taking into account their immune status, these groups are to be categorized as immunocompromised, because the microbiota and immune system of infants is not fully developed and the microbiota composition and immune function decreases qualitatively with age (Delzenne et al. 2005). The only conclusions we can draw from the current supplementation studies in healthy human adults, studies in healthy experimental animals, as well as studies in infants and elderly, is that inulin-type fructan supplementation in healthy human adults will generally result in increased Bifidobacteria numbers in the gut (Buddington et al. 1996,Bouhnik et al. 1999, Menne et al. 2000,Langlands et al. 2004,Bouhnik et al. 2006), increased levels of fecal sIgA (Swanson et al. 2002,Hosono et al. 2003,Nakamura et al. 2004), increased levels of IL-10 and IFN- $\gamma$ in Peyer's patches (Swanson et al. 2002b,Hosono et al. 2003,Nakamura et al. 2004, Roller et al. 2004b) and increased activity of different immune cells in the spleen (Benyacoub et al. 2008, Trushina et al. 2005, Roller et al. 2004b,KellyQuagliana et al. 2003,Stillie et al. 2005), as these are the parameters which are most often reported to have been changed upon supplementation. The evidence for immunomodulation on a systemic level may be somewhat less strong than locally in the gut, however, the local cytokine levels in the gut may have more impact on an immune parameter such as prevention of 


\section{Critical Reviews in Food Science and Nutrition}

infections, since the gut is the largest organ of the human body to be in such close contact with the outside world.

In the following sections we will review the effects of inulin-type fructans on immune structures in the context of the different disease models which have been studied up to now.

\section{Cancer models}

Two studies using experimental animal cancer models focused on immune parameters involved in anti-tumorigenic reactions. In a study by Roller et al. (Roller et al. 2004a), the effects of probiotic Lactobacillus LGG and Bifidobacterium lactis Bb12, and FOS ("Raftilose," chain length range $2-10$, average $4,100 \mathrm{~g} / \mathrm{kg}$ of diet) synbiotic treatment on the immune system of rats were investigated in an azoxymethane (AOM)-induced colon cancer model. Synbiotic supplementation significantly restored Natural Killer cell-like cytotoxicity $(\mathrm{p}<0.01)$ and suppressed proliferative responsiveness of lymphocytes in Peyer's patches of AOM-treated rats. It should be noted that no normal diet or placebo diet group was included in this study and that this alteration of responsiveness may be related to the background of the high fat diet. FOS supplementation significantly stimulated IL-10 production in Peyer's patches and mesenteric lymph nodes of rats not treated with AOM $(\mathrm{p}<0.05)$. In pro- and synbiotic groups, IFN- $\gamma$ production in Peyer's patches was significantly decreased independent of AOM treatment (p<0.05). A study by Forest et al. (Forest et al. 2005) showed that short chain fructans (chain length range 1-4, mostly 3") reduced colon tumor incidence in intestinal neoplasia prone "adenomatous polyposis coli /multiple intestinal neoplasia" (Apc+/Min) mice via a functional

local immune response. Apc is a tumor suppressor gene involved in development of colorectal 


\section{Critical Reviews in Food Science and Nutrition}

cancer (Kartheuser et al. 1995). In the colons of Apc+/Min mice, FOS treatment restored large intestine-intraepithelial lymphocytes (LI-IELs) surface expression of anti-tumorigenic IL-15/IL$15 \mathrm{R} \alpha$. In addition, FOS specifically induced a decrease in the proportion of CD4+ CD25+ LIIELs which are considered to be tumor facilitating cells (Forest et al. 2005). Publications on fiber supplementation in human cancer patients are rare, and mostly discuss FOS, inulin, or FOSenriched inulin in synbiotic mixtures using Lactobacillus LGG and Bifidobacterium lactis Bb12 (Rafter et al. 2007, Roller et al. 2007); or Lactobacillus acidophilus La5, Lactobacillus bulgaricus, Bifidobacterium lactis BB-12, and Streptococcus thermophilus (Roller et al. 2007). These studies demonstrated that supplementation induced secretion of IL-2 and IFN- $\gamma$ by PBMCs and decreased bacterial translocation (Rafter et al. 2007, Reddy et al. 2007, Roller et al. 2007). Results for immunological parameters in experimental animal cancer models and in human colon cancer patients upon inulin-type fructan supplementation are summarized in Table 2. Studies regarding tumor growth and outcome of disease upon supplementation with inulintype fructans have demonstrated anti-carcinogenic properties in multiple experimental animal models (Taper et al. 1997,Taper et al. 1998) and cell lines (Yeh et al. 2007,Klinder et al. 2004). As previously reviewed by Taper et al. (Taper and Roberfroid. 2005) dietary treatment with inulin and/or FOS incorporated in the basal diet for experimental animals: (i) reduced the incidence of mammary tumors induced in Sprague-Dawley rats by methylnitrosourea; (ii) inhibited the growth of transplantable malignant tumors in mice; (iii) decreased the incidence of lung metastases of a malignant tumor implanted intramuscularly in mice. Moreover, dietary treatment with inulin and/or FOS (iv) significantly potentiated the effects of cytotoxic drugs and potentiated the effects of radiotherapy on solid form of transplantable lymphoid tumor. Especially the fermentation products of FOS-enriched inulin ("Synergyl") i.e. SCFA and 


\section{Critical Reviews in Food Science and Nutrition}

Deoxycholic Acid appear to limit tumor growth (Munjal et al. 2009). The most consistent findings were reductions in aberrant crypt foci, tumor incidence and metastasis in models which make use of chemically induced pre-neoplastic lesions or tumors in the colon of rats and mice (Femia et al. 2002,Poulsen et al. 2002,Verghese et al. 2002,Buddington et al. 2002, Taper and Roberfroid. 2002). Only one (preliminary) study in patients with colorectal adenomas was performed so far. This study was an open multicenter study on the effects of FOS. No beneficial effect was found on proliferation at the rectal crypts (Boutron-Ruault et al. 2005). However, from experimental use of human ex vivo cells, significant anti-carcinogenic effects were reported (Burns and Rowland. 2004,Reddy et al. 1997,Reddy. 1998,Rao et al. 1998,Pool-Zobel et al. 2002). Moreover, when applied in a synbiotic protocol, inulin has already shown beneficial effects on inhibition of carcinogenic processes (Misikangas et al. 2005).

The prescription of inulin-type fructans to colon/colorectal cancer patients should be applied with some caution, as there are reports that under certain circumstances, inulin-type fructans can actually enhance proliferation of adenomas (Misikangas et al. 2005, Misikangas et al. 2008,Pajari et al. 2003). It should be noted that these reports involve mice studies and results so far do not show these effects in human colon cancer. The mechanisms behind these effects are not clear and require further investigation. The production and balance of anti-inflammatory and pro-inflammatory/anti-tumorigenic cytokines such as IL-10 and IL-12 respectively may play a role in these observations because anti-inflammatory cytokines could confer an inhibitory effect on the anti-tumorigenic properties of proinflammatory cytokines. On the other hand, inulin-type fructan supplementation has shown promising anti-tumorigenic properties (Forest et al. 2005, Roller et al. 2004b) and further investigation into the underlying mechanisms of these processes, which may involve immunomodulation, is warranted. 


\section{Critical Reviews in Food Science and Nutrition}

\section{Intestinal inflammation models}

Inflammatory Bowel Disease (IBD) is a group of inflammatory conditions of the GI tract. IBD is thought to be caused by a combination of genetic, environmental, and immunological factors (Sartor. 2004) The current paradigm is that these diseases result from a lack of tolerance to resident intestinal bacteria in genetically susceptible hosts (Podolsky. 2002,Strober et al. 2007,Xavier and Podolsky. 2007,Hata et al. 2001, Rath et al. 2001). The major types of IBD are Crohn's Disease (CD) and Ulcerative Colitis (UC) (Crohn et al. 1932). CD and UC share similar symptoms but also differ in substantial features. CD can occur along the entire tract, from mouth to anus, whereas UC specifically affects the large intestine or colon. Another difference is that UC occurs more superficially in the gut lining while CD can also affect deeper layers of the intestine. Another affliction of the intestine is Irritable Bowel Syndrome (IBS); a functional bowel disorder characterized by chronic abdominal pain, discomfort, bloating, and alteration of bowel habits in the absence of any detectable organic cause (van der Horst et al. 2010). Evidence is slowly increasing that inulin-type fructan supplements exert beneficial effects on both bowel movements (Kleessen et al. 1997,Lopez Roman et al. 2008,Gruenwald et al. 2009, Marteau et al. 2011) as well as on GI immune parameters (Lindsay et al. 2006,Bakker-Zierikzee et al. 2006). Supplementation studies have been performed in several animal colitis models as well as in patients with IBD or IBS (Table 3 and 4). Leenen and Dieleman (Leenen and Dieleman. 2007) recently reviewed the effects of pre-, and synbiotics on IBD/IBS. Few studies using prebiotics alone have been performed so far, however results look promising with regard to therapeutic use in treatment of IBD/IBS. FOS-enriched inulin supplementation lowered disease activity scores (Lindsay et al. 2006), fecal calprotectin (a gut inflammation marker) (Casellas et al. 2007), and inulin supplementation lowered pouchitis disease index (Welters et al. 2002). Sigmoidoscopy 


\section{Critical Reviews in Food Science and Nutrition}

scores (i.e. inflammation scores of endoscopy of the distal colon) were reduced, and endoscopically and histologically verified reductions in inflammation of the mucosa of the ileal reservoir were observed (Lindsay et al. 2006, Casellas et al. 2007). mRNA levels of beta defensins 2, 3, and 4 (i.e. antimicrobial proteins) were significantly reduced by treatment while these markers are normally upregulated in active UC (Macfarlane et al. 2005). When applied in synbiotic set up, increased amounts of Bifidobacteria in rectal mucosa were reported, and significant reductions in the expression of molecules that control inflammation in active UC (Macfarlane et al. 2005). TNF $\alpha$, and IL-1a mRNA levels in mucosal tissue were significantly reduced $(\mathrm{p}=0.0175$ and $\mathrm{p}=0.0379)$ but also, a significant increase in IL-10 positive CD11+ DCs and expression of TLR2 and TLR4 was reported (Macfarlane et al. 2005). Beneficial effects in UC patients have been reported (Welters et al. 2002,Macfarlane et al. 2005,Furrie et al. 2005) as supplementation resulted in improvement of the full clinical appearance of chronic inflammation in patients receiving this therapy. In addition to reduction of intestinal inflammation, regeneration of epithelial tissue was observed. To our knowledge no trials have been conducted as yet to determine whether chronic supplementation with inulin-type fructans might ameliorate disease progression, to prevent disease recurrence, or sustain periods of clinical remission. Currently available data concerns trials aiming at investigating the immediate effects (Welters et al. 2002,Macfarlane et al. 2005,Furrie et al. 2005), but it may be worthwhile in future studies to include longer trial periods.

Regarding IBD, studies on treatment of chronic intestinal inflammation using inulin-type fructans have shown major benefits in experimental animal models of colitis (Osman et al. 2006, Ito et al. 2009,Catala et al. 1999,Butel et al. 2002,Videla et al. 2001,Cherbut et al. 2003,Schultz et al. 2004,Hoentjen et al. 2005,Daddaoua et al. 2006, Winkler et al. 2007,Smith et 


\section{Critical Reviews in Food Science and Nutrition}

al. 2008) (Table 3). Several types of experimental animal models exist to mimic IBD; dextran sodium sulfate (DSS)-induced colitis (Osman et al. 2006, Videla et al. 2001, Winkler et al. 2007,Moreau et al. 2003), trinitrobenzene sulphonic acid (TNBS)-induced colitis (Ito et al. 2009,Cherbut et al. 2003,Daddaoua et al. 2006,Holma et al. 2002), and a HLA-B27 transgenic colitis model (Schultz et al. 2004,Hoentjen et al. 2005) were studied in relation to inulin-type prebiotics. In most of these experimental animal models, supplementation rendered statistically significant beneficial effects by reduction of mucosal damage and reduced release of inflammatory mediators such as IL-1 $\beta$ (Osman et al. 2006,Hoentjen et al. 2005,Daddaoua et al. 2006), inducible nitric oxide synthase (Daddaoua et al. 2006), myeloperoxidase activity (Cherbut

et al. 2003,Smith et al. 2008,Lara-Villoslada et al. 2006) cyclooxygenase 2, and mucin 3 (Daddaoua et al. 2006). In conclusion, inulin-type fructans are promising agents to modulate the immune parameters involved in colitis. Underlying mechanisms of these effects are however still unclear and warrant more studies on the effects of inulin-type fructans in experimental animal colitis models. Moreover, in IBD patients, long term intervention studies and follow up are required to determine whether inulin-type fructans might have long term beneficial effects in treatment of these diseases.

IBS is a common disorder of the GI tract and there is increasing evidence to support the role for immune activation in IBS (Hunter et al. 1999,Astegiano et al.2006,Kennedy et al. 2011,Clarke et al. 2010,Wouters and Boeckxstaens. 2011). In a number of patients the onset is triggered by acute gastroenteritis (Spiller et al. 2000,Cumberland et al. 2003,Dunlop et al. 2003, Neal et al. 1997). Evidence of sustained immune activation has been found in these cases (Gwee et al. 1999). However low-grade immune activation without previous acute gastroenteritis can also induce IBS symptoms (Chadwick et al. 2002, Tornblom et al. 2002). The immune 


\section{Critical Reviews in Food Science and Nutrition}

parameters most often increased in IBS, are IL-6 and IL-8 levels (Dinan et al. 2006,Dinan et al. 2010) and baseline and lipopolysaccharide (LPS) induced TNF- $\alpha$, IL-1 $\beta$ and IL-6 levels in IBS patients PBMCs (Liebregts et al. 2007). In experimental IBS rat models, increased TLR expression was found in the colonic mucosa of these animals (McKernan et al. 2009,O'Malley et al. 2011). These altered TLR responses may play a significant role in the enhanced immune activity in IBS (McKernan et al. 2011). The increased risk of developing IBS following gastroenteritis and the co-existence of a disturbed composition of the microbiota, elevated luminal gas production and immune activation, indicate that the gastrointestinal microbiota may be a therapeutic target in IBS. There are no recent clinical trials aimed at studying possible immunological benefits of inulin-type fructans in IBS, although previous prebiotic studies indicate potential health benefit at lower doses, i.e. an intake of 3.5-5g/day (Whelan. 2011). In the studies of Hunter et al., and Astegiano et al. (Hunter et al. 1999,Astegiano et al. 2006), only FOS was applied so possible chain length effects have yet to be evaluated. Two other studies incorporated inulin-type fructans in a synbiotic mixtures (FOS "Actilight" and Bifidobacterium longum W11) / (IBS Active; inulin with Lactobacillus sporogenes, Lactobacillus acidophilus, Streptococcus thermophilus and other additives) (Colecchia et al.2006,Paineau et al. 2008). In these synbiotic combinations with inulin, significant reduction in IBS pain symptoms, abdominal distension, and regulation of bowel movement occurred. Moreover, increased stool frequency, reduced abdominal pain and reduced bloating were reported. Olesen et al. (Olesen and Gudmand-Hoyer. 2000) reported no beneficial effects in a study with IBS patients who were given chicory derived FOS. Concluding from these results, FOS is a promising agent in IBS therapies when combined with the appropriate probiotics and other cofactors. Future IBS studies including inulin-type fructan supplementation should include measurements of the immune 


\section{Critical Reviews in Food Science and Nutrition}

parameters mentioned above to evaluate whether based on immunology, inulin-type fructans can provide therapeutic options.

\section{Systemic immune benefits of inulin type fructan supplementation}

There are several clear physiological links between symptoms of rheumatoid arthritis (RA) and IBD, such as a shared inflammatory cytokine expression pattern and the success of several therapies in both diseases (Videla et al. 2001, Whelan. 2011,Travis. 2006,Lories. 2006,Macfarlane et al. 2008). This may indicate that where inulin-type fructans might alleviate IBD symptoms, RA patients may equally benefit from such supplementation. Experimental data on the benefits of inulin-type fructans in RA are scarce but studies in an HLA-B27 rat models demonstrated reduced severity of colitis as well as reduced severity of arthritis (Schultz et al. 2004,Hoentjen et al. 2005). After inulin-type fructan supplementation a significant reduction in inflammatory scores and pro-inflammatory cytokines was observed (Hoentjen et al. 2005, Whelan. 2011). In adjuvant-induced arthritis in Wistar rats, and type II collagen-induced arthritis in DBA/1 J mice, $\alpha$-GOS supplementation decreased erythema and swelling of limbs, as well as decreased histopathological findings in the hind paw joints (Abe et al. 2004). In conclusion, supplementation with inulin-type fructans and similar prebiotics such as $\alpha$ - GOS as mentioned above, seem to be a promising therapeutic strategy to reduce disease symptoms in experimental animal colitis models and may prove useful in human inflammatory diseases such as IBD and RA (Table 3 and 4). (Schultz et al. 2004,Hoentjen et al. 2005,Macfarlane et al. 2008). However, more experimental animal studies are first required to confirm these beneficial effects and their underlying physiological mechanisms (Macfarlane et al. 2008). 


\section{Critical Reviews in Food Science and Nutrition}

\section{Allergy, infection, and immunization models}

The effects of inulin-type fructans on allergies and immunization have been studied extensively in experimental animal models, mostly in combination with GOS administration, but protocols without GOS already show substantial immunological effects, which are summarized in Table 5. Many studies have been performed in pigs, where supplementation with inulin-type fructans mostly shows significant protective effects in infection models (Gomez-Conde et al. ,Middelbos et al. 2007,McGlone and Fullwood. 2001,Petkevicius et al. 2007,Petkevicius et al. 2003). In one study by Milo et al. supplementation of piglets with $1 \%$ of inulin for 1 week did not affect immune parameters or infection symptoms upon inoculation with Salmonella typhimurium. In a study in dogs, inoculated with Salmonella typhimurium DT104, a 14 day supplementation with inulin or FOS (1\%) improved food intake and enterocyte sloughing and attenuated fever (Apanavicius et al. 2007). Manhart et al. reported that a 16 day supplementation trial with $10 \%$ FOS induced an increased CD4+/CD8+ ratio in an experimental mouse model for LPS-induced endotoxemia (Manhart et al. 2003). Inulin-type fructans have been administered to infants and children because of their potential to modulate the intestinal microbiota and to benefit the development of an adequate innate and adaptive immune response (Table 6). In healthy infants, the most obvious effect upon supplementation was increased levels of $\operatorname{IgA}$ in fecal samples, which can protect against pathogens in the gut lumen (van Hoffen et al. 2009, Scholtens et al. 2008,Bakker-Zierikzee et al. 2006,Halas et al. 2009,Raes et al. 2010). Saavedra et al. (Saavedra and Tschernia. 2002) demonstrated an increase in blood IgG levels after measles vaccination in a 10 week supplementation study with OF/inulin $(7 / 3,0,2 \mathrm{~g} / \mathrm{kg} \mathrm{BW} / \mathrm{d})$ in $7-9$ months old infants. However in a study by Duggan et al.(Duggan et al. 2003) in which 6-12 month old infants were supplemented with OF $(0.7 \mathrm{~g} / \mathrm{d})$, no effect was observed on antibody response after vaccination 


\section{Critical Reviews in Food Science and Nutrition}

with $H$. influenza type B vaccine. Results from these studies may be related to the specific pathogen, or the type of fructans used in the vaccine but further studies are required to investigate these differences.

In both experimental animal studies and human studies, the use of inulin-type fructans has demonstrated beneficial effects on Th1 as well as on Th2 responses upon vaccination or sensitization protocols. Th1 cells normally drive the cellular immunity pathway to fight viruses and other intracellular pathogens, eliminate cancerous cells, and stimulate delayed-type hypersensitivity (DTH) skin reactions (Perez et al. 2010). Th2 cells drive the humoral immunity pathway and up-regulate antibody production to fight extracellular organisms. In a study by Vos et al. (Vos et al. 2006) supplementation of mice which were vaccinated with influenza virus, a 9:1 mixture of GOS/FOS enhanced DTH responses dose-dependently, but a mixture of FOS/inulin did not. Fujitani et al. (Fujitani et al. 2007) describe anti-allergic effects of FOS in Nc/jic mice upon supplementation with 5\% FOS. Schouten et al. (Schouten et al. 2009) demonstrated that a mixture of GOS/FOS inhibited sensitization to orally supplemented whey in mice, but this was only effective when used in synbiotic combination with Bifidobacterium breve. Inulin-type fructans appear to modulate both reactions; stimulating the adaptive immune response in a Th1-direction upon vaccination or sensitization, inhibiting infections (Vos et al. 2006) or Th-2 related immune disorders such as allergies (Vos et al. 2007a,Schouten et al. 2009,Fujitani et al. 2007,Schouten et al. 2011), although in these experimental animal studies, inulin-type fructan effectiveness was most pronounced when used in combination with either GOS or Bifidobacterium breve. On the other hand they can induce increased antibody production (IgA) as part of a Th2 response, increasing clearance of luminal pathogens and reducing the chance of pathogen tissue entry. 


\section{Critical Reviews in Food Science and Nutrition}

Evidence for prevention of incidence of allergies or atopic symptoms in infants was reported by Moro et al. (Moro et al. 2006b), and Arslanoglu et al (Arslanoglu et al. 2008,Arslanoglu et al. 2007) but in these studies inulin-type fructans were only supplemented in combination with GOS. In a study by Raes et al. (Raes et al. 2010) in which infants received breast milk, formula or formula supplemented with GOS/FOS, no clear differences were observed in the investigated immune parameters, but a trend was observed that GOS/FOS supplementation tended to increase blood IgG levels.

In conclusion, reduction of incidence of allergic symptoms or protective effects on development of allergy upon supplementation with inulin-type fructans have been shown in infants (van Hoffen et al. 2009,Scholtens et al. 2008,Bakker-Zierikzee et al. 2006, Halas et al. 2009, Raes et al. 2010). For elderly, promising results have been shown for supporting immune function, including for defense against respiratory infections (Vulevic et al. 2008, Amati et al. 2010,Langkamp-Henken et al. 2004,Langkamp-Henken et al. 2006,Schiffrin et al. 2007) (Table 6). Other groups of patients which may benefit from inulin-type fructan supplementation by means of Th-1/Th-2 modulation are pregnant women (Shadid et al. 2007), or burn patients (Olguin et al. 2005) but the small number of supplementation studies performed with these groups show no beneficial effects as yet. In a study in adult male smokers and non-smokers, 4 out of 23 immunological parameters were changed upon supplementation (Seidel et al. 2007). However, in the experimental set up of this study, inulin was incorporated in prebiotic bread, which also contained linseed and soy fiber so observed effects cannot solely be attributed to inulin intake. More studies in healthy human subjects are required to assess the immunomodulatory potential of inulin-type fructans in healthy conditions. 


\section{Critical Reviews in Food Science and Nutrition}

\section{Possible explanations for the inconsistencies}

Some of the inconsistencies in the studies focusing on the immunomodulating effects of inulintype fructans are caused by pertinent differences in study design and the application of different types of inulin-type fructans. In many studies the type of fructan has not been clearly documented. In part this can be explained by the inconsistent use of nomenclature regarding chain length. The chain length should always be included as it has been shown that chain length is a determining factor for the beneficial effects (Roberfroid et al. 2010,Poulsen et al. 2002,Buddington et al. 2002,Reddy et al. 1997). The mechanisms behind this might be that specifically long chain fructans bind to typical receptors in the membrane and cluster them into membrane microdomains (Figdor and van Spriel. 2010) or influence other membrane lipid dynamics (Vereyken et al. 2003a,Vereyken et al. 2003b,Vereyken et al. 2003c) whereas the shorter chain fructans may lack these properties and exert their effects via different routes. These findings suggest that the DP of fructans influences the efficacy in modulating immune functions and warrant further investigation (Roberfroid et al. 2010).

Many of the studies mentioned in this review report altered cytokine levels upon supplementation with inulin-type fructans. Nowadays a lot is known about the effects that cytokines or chemokines have on humans. The connection between inulin ingestion, the production of cytokines or chemokines, and the observed downstream health effects is gradually becoming clearer. On a chemical and cellular level inulin-type fructans can exert several effects and most pronounced effects are observed in the GALT. Several studies report modulation of IgG (Benyacoub et al. 2008,Hosono et al. 2003,Janardhana et al. 2009, Reddy et al. 1997, Raes et al. 2010), and IgA (Benyacoub et al. 2008,Fujitani et al. 2007,Nakamura et al. 2004,Smith et al. 2008, Thomsen et al. 2005) levels in serum and/or feces, changes in cytokine expression, mainly 


\section{Critical Reviews in Food Science and Nutrition}

IFN- $\gamma$ (Benyacoub et al. 2008,Hosono et al. 2003, Roller et al. 2004b,Roller et al. 2004a, Roller et al. 2007), IL-4 (Trushina et al. 2005, Taper and Roberfroid. 2000), IL-10 (Hosono et al. 2003, Roller et al. 2004b,Roller et al. 2004a,Taper and Roberfroid. 2000,Kidd. 2003) and, IL-12 (Benyacoub et al. 2008), and altered activity of spleen NK cells (Shim et al. 2005, Roller et al. 2004a,Rao et al. 1998). IFN- $\gamma$ and IL-12 are factors responsible for Th1 differentiation, whereas IL-4 promotes Th2 subpopulations (Perez et al. 2010,Newberry and Lorenz. 2005). Regulatory T lymphocytes (Treg) are expanded in response to IL-10 and IL-10 skews the Th1/Th2 balance to Th2 in vivo by selectively blocking IL-12 synthesis by the antigen-presenting cells such as DCs (Newberry and Lorenz. 2005,Whelan. 2011). In addition, IL-4 induces IgA synthesis by follicular B lymphocytes in the Peyer's patches (Guilliano et al. 2001). These B lymphocytes, plasma-cell precursors, will migrate, maturate, and undergo clonal expansion, and finally migrate to the intestinal lamina propria, where they finalize their maturation into IgA-secreting cells (Chin et al. 2003). A great variety of factors can influence this migration, including the cytokines (Brandtzaeg and Johansen. 2005) induced by the inulin-type fructans. From this expression pattern of cytokines it appears that several types of $\mathrm{T}$ cell responses are induced by inulin-type fructans. Because of this complex interplay, and depending on the experimental set up, different outcomes may be observed.

\section{Future studies with inulin-type fructans}

There are many biomarkers to quantify immunomodulation in human nutrition intervention studies, but the repercussions of variations in these markers are still unclear, especially in healthy people. A review by Albers et al. (Albers et al. 2005) discusses the suitability of a large panel of biomarkers for the evaluation of nutritional intervention. However, the choice of immune 


\section{Critical Reviews in Food Science and Nutrition}

markers needs to be correlated with the particular condition that is being assessed, the relevant clinical end-points, and whether any immune markers are differentially expressed in disease and control populations (Macfarlane et al. 2008). Concluding from this review, recommended biomarkers, typically suitable for inulin-type fructan supplementation studies are $\operatorname{IgG}$ and $\operatorname{IgA}$ levels in serum and feces, cytokine expression patterns in the GALT, and NK cell activity in the spleen. Measurements of these markers may be affected by age and gender, and they might vary because of other external confounding factors such as stress, smoking, and alcohol intake (Macfarlane et al. 2008). This necessitates careful selection of the control subjects (Macfarlane et al. 2008). Patient populations which are likely to benefit from inulin-type fructan supplementation include allergic individuals, IBD patients, RA patients and likely also patients suffering from other chronic inflammatory afflictions. Well designed, randomized placebo controlled trials are useful to evaluate possible benefit these patient groups may derive from inulin-type prebiotic supplementation.

The physiological effects of ingested inulin-type fructans are likely the combined effects of circumstances including an altered gut microbiota, the presence of produced fermentation products in the gut, and direct effects on gut epithelium and GALT, which complicates the analysis of the induced health effects. To investigate the direct effects, germ free experimental animal models or finely designed SPF experimental animal models and in vitro assays with suitable cell lines may shed more light on the induced physiological processes. Specific molecular or cellular effects which are reported repeatedly throughout literature are important to consider in unraveling the mechanisms behind the observed health benefits and can form a basis

for further explorative research. It appears that ingestion of inulin type fructans affects a spectrum of immune reactions in the body including Th1 (Rafter et al. 2007,Benyacoub et al. 


\section{Critical Reviews in Food Science and Nutrition}

2008,Roller et al. 2004a,Roller et al. 2007) Th2 (Trushina et al. 2005,Stillie et al. 2005), antiinflammatory reactions (Hosono et al. 2003, Roller et al. 2004b,Stillie et al. 2005, Roller et al. 2004a,Langkamp-Henken et al. 2004), B cell activity (Ito et al. 2009, van Hoffen et al.2009,Janardhana et al. 2009,Stillie et al. 2005,Pasare and Medzhitov. 2005) and NK cell activity (Le Poul et al. 2003,Shim et al. 2005,Langkamp-Henken et al. 2004). Depending on the research question, in vitro studies may provide useful information about the typical processes which are induced upon ingestion. In vitro studies into the signalling capacity of inulin-type fructans could entail the use of NK cell activity reporter assays. Another signalling target could be B cell activation; Peyer's patch DCs are able to induce B cell maturation and IgA production under influence of intestinal bacteria, via Peyer's patch DC derived cytokines such as B-cell activating factor (BAFF) and A Proliferation- Inducing Ligand (APRIL) (Heer et al. 2007,Pedersen et al. 1997). It is possible that inulin-type fructans could exert the same effect. Another possibility of promoted IgA production under influence of inulin-type fructans could be due to the traditional activation of T cells in the Peyer's patch follicles by DCs which have sampled the intestinal lumen and have encountered inulin molecules, followed by $\mathrm{T}$ helper cell mediated B cell maturation and $\operatorname{Ig}$ A production. Finally, it would be interesting to see whether direct ligation of B cell TLRs (Heer et al. 2007,Hijova et al. 2009,Parnell and Reimer. 2010) by inulin-type fructans could result in IgA production. Regarding the altered cytokine levels in inulin-type fructan supplementation studies, it would be interesting to investigate which immune cell types are capable of recognizing inulin-type fructans and of mounting a subsequent cytokine response. This may be a wide range of cell types because many cell types express TLRs and CLRs. From there, results can be translated to the relevant populations which may actually come in contact with fructan molecules after their ingestion. Moreover, the capacity of APCs to report 


\section{Critical Reviews in Food Science and Nutrition}

the presence of inulin-type fructans or parts of the molecules to effector cells is still an uncharted area of research which deserves further exploration.

\section{CONCLUDING REMARKS AND FUTURE PERSPECTIVES}

The European Food Safety Authority (EFSA) panel aims to create guidance documents on the scientific requirements for the substantiation of nutritional health claims, including claims related to gut and immune function. They strive to include input from all stakeholders such as applicants for health claims, non-governmental organizations, industry organizations, and academia. This is an ongoing process of gathering input from the scientific community and all interested parties in order to provide clear answers on how to make a certified health claim about a product or ingredient. The status quo of inulin-type fructans is certainly that it a functional food, but that for more specific claims require more scientific evidence. The immunomodulatory properties are convincing, but to unravel the impact this modulation has on more specific components of the immune system such as resistance against intestinal infections or potentiation of vaccination programs, more studies are highly recommended. There are still missing links to fully comprehend the effects of inulin type fructans and the underlying signalling mechanisms. From the results of this literature study, it can be concluded that immunological effects are elicited by ingestion of inulin type fructans, in experimental animals as well as in humans. This could be caused by several factors or a combination of factors, such as the effect of increased Bifidobacteria numbers per se (Kelly. 2008,Kelly. 2009), and/or the increase of fermentation products such as SCFAs. These could bind to GPRs and other immune receptors (Delzenne et al. 


\section{Critical Reviews in Food Science and Nutrition}

2005,Spahn and Kucharzik. 2004). Moreover, it is possible that the inulin itself ligates specific immune receptors such as TLRs or CLRs (Adib-Conquy et al. 2003,Chermesh et al. 2007). The extent to which each of these factors is individually responsible for the reported health effects remains to be determined. To study any direct effects, in vitro studies with different relevant cell types such as gut epithelium or intestinal DCs or lymphocytes can be useful to first study signal transduction upon contact of these cell types. Follow up could include supplementation studies with inulin-type fructans in a germ free experimental animal model. This can render new information about the fate of inulin after ingestion. However, ultimately this does not represent the natural situation of the subject and results should be confirmed in the context of a healthy individual. 
Critical Reviews in Food Science and Nutrition

\section{ACKNOWLEDGEMENTS}

Within the framework of the Carbohydrate Competence Center, this research has been financially supported by the European Union, the European Regional Development Fund, and The Northern Netherlands Provinces (Samenwerkingsverband Noord-Nederland), KOERS NOORD. 


\section{REFERENCES}

Abe, C., Fujita, K., Kikuchi, E., Hirano, S., Kuboki, H., Yamashita, A., Hashimoto, H., Mori, S., and Okada, M. (2004). Effects of alpha-linked galactooligosaccharide on adjuvant-induced arthritis in Wistar rats and type II collagen-induced arthritis in DBA/1J mice. Int J Tissue React. 26: $65-73$.

Abreu, M. T. (2010). Toll-like receptor signalling in the intestinal epithelium: how bacterial recognition shapes intestinal function. Nat Rev Immunol. 10: 131-144.

Adib-Conquy, M., Moine, P., Asehnoune, K., Edouard, A., Espevik, T., Miyake, K., Werts, C., and Cavaillon, J. M. (2003). Toll-like receptor-mediated tumor necrosis factor and interleukin-10 production differ during systemic inflammation. Am J Respir Crit Care Med. 168: 158-164.

Albers, R., Antoine, J. M., Bourdet-Sicard, R., Calder, P. C., Gleeson, M., Lesourd, B., Samartin, S., Sanderson, I. R., Van Loo, J., Vas Dias, F. W., and Watzl, B. (2005). Markers to measure immunomodulation in human nutrition intervention studies. Br J Nutr. 94: 452-481.

Alles, M. S., de Roos, N. M., Bakx, J. C., van de Lisdonk, E., Zock, P. L., and Hautvast, G. A. (1999). Consumption of fructooligosaccharides does not favorably affect blood glucose and serum lipid concentrations in patients with type 2 diabetes. Am J Clin Nutr. 69: 64-69.

Alles, M. S., Hautvast, J. G., Nagengast, F. M., Hartemink, R., Van Laere, K. M., and Jansen, J. B. (1996). Fate of fructo-oligosaccharides in the human intestine. Br J Nutr. 76: 211-221.

Amati, L., Marzulli, G., Martulli, M., Pugliese, V., Caruso, C., Candore, G., Vasto, S., and Jirillo, E. (2010). Administration of a synbiotic to free-living elderly and evaluation of serum cytokines. A pilot study. Curr Pharm Des. 16: 854-858.

Apanavicius, C. J., Powell, K. L., Vester, B. M., Karr-Lilienthal, L. K., Pope, L. L., Fastinger, N. D., Wallig, M. A., Tappenden, K. A., and Swanson, K. S. (2007). Fructan supplementation and infection affect food intake, fever, and epithelial sloughing from Salmonella challenge in weanling puppies. $J$ Nutr. 137: 1923-1930.

Arslanoglu, S., Moro, G. E., and Boehm, G. (2007). Early supplementation of prebiotic oligosaccharides protects formula-fed infants against infections during the first 6 months of life. J Nutr. 137: 2420-2424.

Arslanoglu, S., Moro, G. E., Schmitt, J., Tandoi, L., Rizzardi, S., and Boehm, G. (2008). Early dietary intervention with a mixture of prebiotic oligosaccharides reduces the incidence of allergic manifestations and infections during the first two years of life. J Nutr. 138: 1091-1095.

Astegiano, M., Pellicano, R., Terzi, E., Simondi, D., and Rizzetto, M. (2006). Treatment of irritable bowel syndrome. A case control experience. Minerva Gastroenterol Dietol.52: 359-363. 
Bakker-Zierikzee, A. M., Tol, E. A., Kroes, H., Alles, M. S., Kok, F. J., and Bindels, J. G. (2006). Faecal SIgA secretion in infants fed on pre- or probiotic infant formula. Pediatr Allergy Immunol. 17: 134-140.

Benyacoub, J., Rochat, F., Saudan, K. Y., Rochat, I., Antille, N., Cherbut, C., von der Weid, T., Schiffrin, E. J., and Blum, S. (2008). Feeding a diet containing a fructooligosaccharide mix can enhance Salmonella vaccine efficacy in mice. J Nutr. 138: 123-129.

Bolognani, F., Rumney, C. J., Pool-Zobel, B. L., and Rowland, I. R. (2001). Effect of lactobacilli, bifidobacteria and inulin on the formation of aberrant crypt foci in rats. Eur J Nutr. 40: 293-300.

Bouhnik, Y., Achour, L., Paineau, D., Riottot, M., Attar, A., and Bornet, F. (2007). Four week short chain fructo-oligosaccharides ingestion leads to increasing fecal bifidobacteria and cholesterol excretion in healthy elderly volunteers. Nutr J. 6: 42.

Bouhnik, Y., Flourie, B., Riottot, M., Bisetti, N., Gailing, M. F., Guibert, A., Bornet, F., and Rambaud, J. C. (1996). Effects of fructo-oligosaccharides ingestion on fecal bifidobacteria and selected metabolic indexes of colon carcinogenesis in healthy humans. Nutr Cancer. 26: 21-29.

Bouhnik, Y., Raskine, L., Simoneau, G., Paineau, D., and Bornet, F. (2006). The capacity of short-chain fructo-oligosaccharides to stimulate faecal bifidobacteria: a dose-response relationship study in healthy humans. Nutr J. 5: 8.

Bouhnik, Y., Vahedi, K., Achour, L., Attar, A., Salfati, J., Pochart, P., Marteau, P., Flourie, B., Bornet, F., and Rambaud, J. C. (1999). Short-chain fructo-oligosaccharide administration dosedependently increases fecal bifidobacteria in healthy humans. J Nutr. 129: 113-116.

Boutron-Ruault, M. C., Marteau, P., Lavergne-Slove, A., Myara, A., Gerhardt, M. F., Franchisseur, C., Bornet, F., and Eripolyp Study Group. (2005). Effects of a 3-mo consumption of short-chain fructo-oligosaccharides on parameters of colorectal carcinogenesis in patients with or without small or large colorectal adenomas. Nutr Cancer. 53: 160-168.

Brandtzaeg, P. and Johansen, F. E. (2005). Mucosal B cells: phenotypic characteristics, transcriptional regulation, and homing properties. Immunol Rev. 206: 32-63.

Brown, A. J., Goldsworthy, S. M., Barnes, A. A., Eilert, M. M., Tcheang, L., Daniels, D., Muir, A. I., Wigglesworth, M. J., Kinghorn, I., Fraser, N. J., Pike, N. B., Strum, J. C., Steplewski, K. M., Murdock, P. R., Holder, J. C., Marshall, F. H., Szekeres, P. G., Wilson, S., Ignar, D. M., Foord, S. M., Wise, A., and Dowell, S. J. (2003). The Orphan G protein-coupled receptors GPR41 and GPR43 are activated by propionate and other short chain carboxylic acids. J Biol Chem. 278: 11312-11319.

Bruhwyler, J., Carreer, F., Demanet, E., and Jacobs, H. (2008). Digestive tolerance of inulin-type fructans: a double-blind, placebo-controlled, cross-over, dose-ranging, randomized study in healthy volunteers. Int J Food Sci Nutr.: 1-11. 
Brunser, O., Gotteland, M., Cruchet, S., Figueroa, G., Garrido, D., and Steenhout, P. (2006). Effect of a milk formula with prebiotics on the intestinal microbiota of infants after an antibiotic treatment. Pediatr Res. 59: 451-456.

Buddington, K. K., Donahoo, J. B., and Buddington, R. K. (2002). Dietary oligofructose and inulin protect mice from enteric and systemic pathogens and tumor inducers. J Nutr. 132: 472477.

Buddington, R. K., Williams, C. H., Chen, S. C., and Witherly, S. A. (1996). Dietary supplement of neosugar alters the fecal flora and decreases activities of some reductive enzymes in human subjects. Am J Clin Nutr. 63: 709-716.

Bunout, D., Hirsch, S., Pia de la Maza, M., Munoz, C., Haschke, F., Steenhout, P., Klassen, P., Barrera, G., Gattas, V., and Petermann, M. (2002). Effects of prebiotics on the immune response to vaccination in the elderly. JPEN J Parenter Enteral Nutr. 26:372-376.

Burns, A. J. and Rowland, I. R. (2004). Antigenotoxicity of probiotics and prebiotics on faecal water-induced DNA damage in human colon adenocarcinoma cells. Mutat Res. 551: 233-243.

Carabin, I. G. and Flamm, W. G. (1999). Evaluation of safety of inulin and oligofructose as dietary fiber. Regul Toxicol Pharmacol. 30: 268-282.

Casellas, F., Borruel, N., Torrejon, A., Varela, E., Antolin, M., Guarner, F., and Malagelada, J. R. (2007). Oral oligofructose-enriched inulin supplementation in acute ulcerative colitis is well tolerated and associated with lowered faecal calprotectin. Aliment Pharmacol Ther. 25: 10611067.

Chadwick, V. S., Chen, W. X., Shu, D. R., Paulus, B., Bethwaite, P., Tie, A., and Wilson, I. (2002). Activation of the mucosal immune system in irritable bowel syndrome. Gastroenterology. 122: 1778-1783.

Cherbut, C., Michel, C., and Lecannu, G. (2003). The prebiotic characteristics of fructooligosaccharides are necessary for reduction of TNBS-induced colitis in rats. J Nutr. 133: 21-27.

Chermesh, I., Tamir, A., Reshef, R., Chowers, Y., Suissa, A., Katz, D., Gelber, M., Halpern, Z., Bengmark, S., and Eliakim, R. (2007). Failure of Synbiotic 2000 to prevent postoperative recurrence of Crohn's disease. Dig Dis Sci. 52: 385-389.

Chieppa, M., Rescigno, M., Huang, A. Y., and Germain, R. N. (2006). Dynamic imaging of dendritic cell extension into the small bowel lumen in response to epithelial cell TLR engagement. J Exp Med. 203: 2841-2852.

Chin, R., Wang, J., and Fu, Y. X. (2003). Lymphoid microenvironment in the gut for immunoglobulin A and inflammation. Immunol Rev. 195: 190-201. 
Clarke, G., Fitzgerald, P., Hennessy, A. A., Cassidy, E. M., Quigley, E. M., Ross, P., Stanton, C., Cryan, J. F., and Dinan, T. G. (2010). Marked elevations in proinflammatory polyunsaturated fatty acid metabolites in females with irritable bowel syndrome. J Lipid Res. 51: 1186-1192.

Colecchia, A., Vestito, A., La Rocca, A., Pasqui, F., Nikiforaki, A., Festi, D., and Symbiotic Study Group. (2006). Effect of a symbiotic preparation on the clinical manifestations of irritable bowel syndrome, constipation-variant. Results of an open, uncontrolled multicenter study. Minerva Gastroenterol Dietol. 52: 349-358.

Covington, D. K., Briscoe, C. A., Brown, A. J., and Jayawickreme, C. K. (2006). The G proteincoupled receptor 40 family (GPR40-GPR43) and its role in nutrient sensing. Biochem Soc Trans. 34: 770-773.

Crohn, B. B., Ginsberg, L., and Oppenheimer, G. D. (1932). Regional enteritis. A pathological and clinical entity. JAMA. 99: 1323-1329.

Cumberland, P., Sethi, D., Roderick, P. J., Wheeler, J. G., Cowden, J. M., Roberts, J. A., Rodrigues, L. C., Hudson, M. J., Tompkins, D. S., and IID Study Executive. (2003). The infectious intestinal disease study of England: a prospective evaluation of symptoms and health care use after an acute episode. Epidemiol Infect. 130: 453-460.

Cummings, J. H., Macfarlane, G. T., and Englyst, H. N. (2001). Prebiotic digestion and fermentation. Am J Clin Nutr. 73: 415S-420S.

Daddaoua, A., Puerta, V., Requena, P., Martinez-Ferez, A., Guadix, E., de Medina, F. S., Zarzuelo, A., Suarez, M. D., Boza, J. J., and Martinez-Augustin, O. (2006). Goat milk oligosaccharides are anti-inflammatory in rats with hapten-induced colitis. J Nutr. 136: 672-676.

de Kivit, S., Kraneveld, A. D., Garssen, J., and Willemsen, L. E. (2011). Glycan recognition at the interface of the intestinal immune system: Target for immune modulation via dietary components. Eur J Pharmacol. 668 Suppl 1:S124-32.

de Vrese, M. and Schrezenmeir, J. (2008). Probiotics, prebiotics, and synbiotics. Adv Biochem Eng Biotechnol. 111: 1-66.

Delzenne, N. M., Cani, P. D., Daubioul, C., and Neyrinck, A. M. (2005). Impact of inulin and oligofructose on gastrointestinal peptides. Br J Nutr. 93 Suppl 1: S157-61.

Delzenne, N. M., Cani, P. D., and Neyrinck, A. M. (2007). Modulation of glucagon-like peptide 1 and energy metabolism by inulin and oligofructose: experimental data. $J$ Nutr. 137: 2547S$2551 \mathrm{~S}$.

Dinan, T. G., Cryan, J., Shanahan, F., Keeling, P. W., and Quigley, E. M. (2010). IBS: An epigenetic perspective. Nat Rev Gastroenterol Hepatol. 7: 465-471. 
Dinan, T. G., Quigley, E. M., Ahmed, S. M., Scully, P., O'Brien, S., O'Mahony, L., O'Mahony, S., Shanahan, F., and Keeling, P. W. (2006). Hypothalamic-pituitary-gut axis dysregulation in irritable bowel syndrome: plasma cytokines as a potential biomarker? Gastroenterology. 130: 304-311.

Dunlop, S. P., Jenkins, D., Neal, K. R., and Spiller, R. C. (2003). Relative importance of enterochromaffin cell hyperplasia, anxiety, and depression in postinfectious IBS. Gastroenterology. 125: 1651-1659.

Eiwegger, T., Stahl, B., Haidl, P., Schmitt, J., Boehm, G., Dehlink, E., Urbanek, R., and Szepfalusi, Z. (2010). Prebiotic oligosaccharides: in vitro evidence for gastrointestinal epithelial transfer and immunomodulatory properties. Pediatr Allergy Immunol. 21: 1179-1188.

Elinav, E., Strowig, T., Henao-Mejia, J., and Flavell, R. A. (2011). Regulation of the antimicrobial response by NLR proteins. Immunity. 34: 665-679.

Femia, A. P., Luceri, C., Dolara, P., Giannini, A., Biggeri, A., Salvadori, M., Clune, Y., Collins, K. J., Paglierani, M., and Caderni, G. (2002). Antitumorigenic activity of the prebiotic inulin enriched with oligofructose in combination with the probiotics Lactobacillus rhamnosus and Bifidobacterium lactis on azoxymethane-induced colon carcinogenesis in rats. Carcinogenesis. 23: 1953-1960.

Figdor, C. G. and van Spriel, A. B. (2010). Fungal pattern-recognition receptors and tetraspanins: partners on antigen-presenting cells. Trends Immunol. 31: 91-96.

Forest, V., Pierre, F., Bassonga, E., Meflah, K., and Menanteau, J. (2005). Large intestine intraepithelial lymphocytes from $\mathrm{Apc}+/+$ and $\mathrm{Apc}+/ \mathrm{Min}$ mice and their modulation by indigestible carbohydrates: the IL-15/IL-15R alpha complex and CD4+ CD25+ T cells are the main targets. Cancer Immunol Immunother. 54: 78-86.

Fujitani, S., Ueno, K., Kamiya, T., Tsukahara, T., Ishihara, K., Kitabayashi, T., and Itabashi, K. (2007). Increased number of CCR4-positive cells in the duodenum of ovalbumin-induced food allergy model Nc/jic mice and antiallergic activity of fructooligosaccharides. Allergol Int. 56: 131-138.

Furrie, E., Macfarlane, S., Kennedy, A., Cummings, J. H., Walsh, S. V., O'neil, D. A., and Macfarlane, G. T. (2005). Synbiotic therapy (Bifidobacterium longum/Synergy 1) initiates resolution of inflammation in patients with active ulcerative colitis: a randomised controlled pilot trial. Gut. 54: 242-249.

Gibson, G. R., Beatty, E. R., Wang, X., and Cummings, J. H. (1995). Selective stimulation of bifidobacteria in the human colon by oligofructose and inulin. Gastroenterology. 108: 975-982.

Gibson, G. R. and Roberfroid, M. B. (1995). Dietary modulation of the human colonic microbiota: introducing the concept of prebiotics. J Nutr. 125: 1401-1412. 
Gomez-Conde, M. S., Garcia, J., Chamorro, S., Eiras, P., Rebollar, P. G., Perez de Rozas, A., Badiola, I., de Blas, C., and Carabano, R. (2007). Neutral detergent-soluble fiber improves gut barrier function in twenty-five-day-old weaned rabbits. J Anim Sci. 85:3313-3321.

Gruenwald, J., Busch, R., and Bentley, C. (2009). Efficacy and tolerability of Laxatan Granulat in patients with chronic constipation. Clin Exp Gastroenterol. 2: 95-100.

Guigoz, Y., Rochat, F., and Perruisseau-Carrier, G. (2002). Effects of oligosaccharide on the faecal flora and nonspecific immunesystem in elderly people. Nutr Res. 22: 13-25.

Guilliano, M. J., Foxx-Orenstein, A. E., and Lebman, D. A. (2001). The microenvironment of human Peyer's patches inhibits the increase in CD38 expression associated with the germinal center reaction. J Immunol. 166: 2179-2185.

Gwee, K. A., Leong, Y. L., Graham, C., McKendrick, M. W., Collins, S. M., Walters, S. J., Underwood, J. E., and Read, N. W. (1999). The role of psychological and biological factors in postinfective gut dysfunction. Gut. 44: 400-406.

Halas, D., Hansen, C. F., and Hampson, D. J. (2009). Effect of dietary supplementation with inulin and/or benzoic acid on the incidence and severity of post-weaning diarrhoea in weaner pigs after experimental challenge with enterotoxigenic Escherichia coli. Arch Anim Nutr. 63: 267-280.

Hapfelmeier, S., Muller, A. J., Stecher, B., Kaiser, P., Barthel, M., Endt, K., Eberhard, M., Robbiani, R., Jacobi, C. A., Heikenwalder, M., Kirschning, C., Jung, S., Stallmach, T., Kremer, M., and Hardt, W. D. (2008). Microbe sampling by mucosal dendritic cells is a discrete, MyD88independent step in DeltainvG S. Typhimurium colitis. $J$ Exp Med. 205: 437-450.

Harrington, L. E., Hatton, R. D., Mangan, P. R., Turner, H., Murphy, T. L., Murphy, K. M., and Weaver, C. T. (2005). Interleukin 17-producing CD4+ effector T cells develop via a lineage distinct from the Thelper type 1 and 2 lineages. Nat Immunol. 6: 1123-1132.

Harrington, L. E., Mangan, P. R., and Weaver, C. T. (2006). Expanding the effector CD4 T-cell repertoire: the Th17 lineage. Curr Opin Immunol. 18: 349-356.

Hata, K., and oh, A., Sato, H., Araki, Y., Tanaka, M., Tsujikawa, T., Fujiyama, Y., and Bamba, T. (2001). Sequential changes in luminal microflora and mucosal cytokine expression during developing of colitis in HLA-B27/beta2-microglobulin transgenic rats. Scand J Gastroenterol. 36: 1185-1192.

Heer, A. K., Shamshiev, A., Donda, A., Uematsu, S., Akira, S., Kopf, M., and Marsland, B. J. (2007). TLR signaling fine-tunes anti-influenza B cell responses without regulating effector $\mathrm{T}$ cell responses. J Immunol. 178: 2182-2191.

Hijova, E., Chmelarova, A., Bomba, A., and Zitnan, R. (2009). Prebiotic foodstuffs and their health benefits in experiment. Bratisl Lek Listy. 110: 523-525. 
Hoentjen, F., Welling, G. W., Harmsen, H. J., Zhang, X., Snart, J., Tannock, G. W., Lien, K., Churchill, T. A., Lupicki, M., and Dieleman, L. A. (2005). Reduction of colitis by prebiotics in HLA-B27 transgenic rats is associated with microflora changes and immunomodulation. Inflamm Bowel Dis. 11: 977-985.

Holma, R., Juvonen, P., Asmawi, M. Z., Vapaatalo, H., and Korpela, R. (2002). Galacto oligosaccharides stimulate the growth of bifidobacteria but fail to attenuate inflammation in experimental colitis in rats. Scand J Gastroenterol. 37: 1042-1047.

Hooper, L. V. and Macpherson, A. J. (2010). Immune adaptations that maintain homeostasis with the intestinal microbiota. Nat Rev Immunol. 10: 159-169.

Hosono, A., Ozawa, A., Kato, R., Ohnishi, Y., Nakanishi, Y., Kimura, T., and Nakamura, R. (2003). Dietary fructooligosaccharides induce immunoregulation of intestinal IgA secretion by murine Peyer's patch cells. Biosci Biotechnol Biochem. 67: 758-764.

Hughes, R. and Rowland, I. R. (2001). Stimulation of apoptosis by two prebiotic chicory fructans in the rat colon. Carcinogenesis. 22: 43-47.

Hunter, J. O., Tuffnell, Q., and Lee, A. J. (1999). Controlled trial of oligofructose in the management of irritable bowel syndrome. J Nutr. 129: 1451S-3S.

Ito, H., Tanabe, H., Kawagishi, H., Tadashi, W., Yasuhiko, T., Sugiyama, K., Kiriyama, S., and Morita, T. (2009). Short-chain inulin-like fructans reduce endotoxin and bacterial translocations and attenuate development of TNBS-induced colitis in rats. Dig Dis Sci. 54: 21002108.

Janardhana, V., Broadway, M. M., Bruce, M. P., Lowenthal, J. W., Geier, M. S., Hughes, R. J., and Bean, A. G. (2009). Prebiotics modulate immune responses in the gut associated lymphoid tissue of chickens. J Nutr. 139: 1404-1409.

Janeway, C. A.,Jr. (1989). Approaching the asymptote? Evolution and revolution in immunology. Cold Spring Harb Symp Quant Biol. 54 Pt 1: 1-13.

Kapiki, A., Costalos, C., Oikonomidou, C., Triantafyllidou, A., Loukatou, E., and Pertrohilou, V. (2007). The effect of a fructo-oligosaccharide supplemented formula on gut flora of preterm infants. Early Hum Dev. 83: 335-339. Kaplan, H. and Hutkins, R. W. (2000). Fermentation of fructooligosaccharides by lactic acid bacteria and bifidobacteria. Appl Environ Microbiol. 66: 2682-2684.

Karczewski, J., Troost, F. J., Konings, I., Dekker, J., Kleerebezem, M., Brummer, R. J., and Wells, J. M. (2010). Regulation of human epithelial tight junction proteins by Lactobacillus plantarum in vivo and protective effects on the epithelial barrier. Am J Physiol Gastrointest Liver Physiol. 298: G851-9. 
Kartheuser, A., West, S., Walon, C., Curtis, A., Hamzehloei, T., Lannoy, N., Michiels, G., Smaers, M., Chapman, P., and Burn, J. (1995). The genetic background of familial adenomatous polyposis. Linkage analysis, the APC gene identification and mutation screening. Acta Gastroenterol Belg. 58: 433-451.

Kelly, G. (2009). Inulin-type prebiotics: a review. (Part 2). Altern Med Rev. 14: 36-55.

Kelly, G. (2008). Inulin-type prebiotics--a review: part 1. Altern Med Rev. 13: 315-329.

Kelly-Quagliana, K. A., Nelson, P. D., and Buddington, R. K. (2003). Dietary oligofructose and inulin modulate immune functions in mice. Nutr Res. 23: 257-267.

Kennedy, P. J., Clarke, G., Quigley, E. M., Groeger, J. A., Dinan, T. G., and Cryan, J. F. (2011). Gut memories: Towards a cognitive neurobiology of irritable bowel syndrome. Neurosci Biobehav Rev.

Kidd, P. (2003). Th1/Th2 balance: the hypothesis, its limitations, and implications for health and disease. Altern Med Rev. 8: 223-246.

Kim, S. H., Lee da, H., and Meyer, D. (2007). Supplementation of baby formula with native inulin has a prebiotic effect in formula-fed babies. Asia Pac J Clin Nutr. 16: 172-177.

Kleessen, B., Sykura, B., Zunft, H. J., and Blaut, M. (1997). Effects of inulin and lactose on fecal microflora, microbial activity, and bowel habit in elderly constipated persons. Am J Clin Nutr. 65: 1397-1402.

Klinder, A., Forster, A., Caderni, G., Femia, A. P., and Pool-Zobel, B. L. (2004). Fecal water genotoxicity is predictive of tumor-preventive activities by inulin-like oligofructoses, probiotics (Lactobacillus rhamnosus and Bifidobacterium lactis), and their synbiotic combination. Nutr Cancer. 49: 144-155.

Kolida, S., Tuohy, K., and Gibson, G. R. (2002). Prebiotic effects of inulin and oligofructose. $\mathrm{Br}$ J Nutr. 87 Suppl 2: S193-7.

Kurowska-Stolarska, M., Kewin, P., Murphy, G., Russo, R. C., Stolarski, B., Garcia, C. C., Komai-Koma, M., Pitman, N., Li, Y., Niedbala, W., McKenzie, A. N., Teixeira, M. M., Liew, F. Y., and $\mathrm{Xu}, \mathrm{D}$. (2008). IL-33 induces antigen-specific IL-5+ T cells and promotes allergicinduced airway inflammation independent of IL-4. J Immunol. 181:4780-4790.

Langkamp-Henken, B., Bender, B. S., Gardner, E. M., Herrlinger-Garcia, K. A., Kelley, M. J., Murasko, D. M., Schaller, J. P., Stechmiller, J. K., Thomas, D. J., and Wood, S. M. (2004). Nutritional formula enhanced immune function and reduced days of symptoms of upper respiratory tract infection in seniors. J Am Geriatr Soc. 52: 3-12.

Langkamp-Henken, B., Wood, S. M., Herlinger-Garcia, K. A., Thomas, D. J., Stechmiller, J. K., Bender, B. S., Gardner, E. M., DeMichele, S. J., Schaller, J. P., and Murasko, D. M. (2006). 


\section{Critical Reviews in Food Science and Nutrition}

Nutritional formula improved immune profiles of seniors living in nursing homes. $J$ Am Geriatr Soc. 54: 1861-1870.

Langlands, S. J., Hopkins, M. J., Coleman, N., and Cummings, J. H. (2004). Prebiotic carbohydrates modify the mucosa associated microflora of the human large bowel. Gut. 53: 1610-1616.

Lara-Villoslada, F., Debras, E., Nieto, A., Concha, A., Galvez, J., Lopez-Huertas, E., Boza, J., Obled, C., and Xaus, J. (2006). Oligosaccharides isolated from goat milk reduce intestinal inflammation in a rat model of dextran sodium sulfate-induced colitis. Clin Nutr. 25: 477-488.

Le Poul, E., Loison, C., Struyf, S., Springael, J. Y., Lannoy, V., Decobecq, M. E., Brezillon, S., Dupriez, V., Vassart, G., Van Damme, J., Parmentier, M., and Detheux, M. (2003). Functional characterization of human receptors for short chain fatty acids and their role in polymorphonuclear cell activation. J Biol Chem. 278: 25481-25489.

Leenen, C. H. and Dieleman, L. A. (2007). Inulin and oligofructose in chronic inflammatory bowel disease. J Nutr. 137: 2572S-2575S.

Liebregts, T., Adam, B., Bredack, C., Roth, A., Heinzel, S., Lester, S., Downie-Doyle, S., Smith, E., Drew, P., Talley, N. J., and Holtmann, G. (2007). Immune activation in patients with irritable bowel syndrome. Gastroenterology. 132: 913-920.

Lindsay, J. O., Whelan, K., Stagg, A. J., Gobin, P., Al-Hassi, H. O., Rayment, N., Kamm, M. A., Knight, S. C., and Forbes, A. (2006). Clinical, microbiological, and immunological effects of fructo-oligosaccharide in patients with Crohn's disease. Gut. 55: 348-355.

Lomax, A. R. and Calder, P. C. (2009). Probiotics, immune function, infection and inflammation: a review of the evidence from studies conducted in humans. Curr Pharm Des. 15: 1428-1518.

Loo, Y. M. and Gale, M.,Jr. (2011). Immune signaling by RIG-I-like receptors. Immunity. 34: 680-692.

Lopez Roman, J., Martinez Gonzalvez, A. B., Luque, A., Pons Minano, J. A., Vargas Acosta, A., Iglesias, J. R., Hernandez, M., and Villegas, J. A. (2008). The effect of a fibre enriched dietary milk product in chronic primary idiopatic constipation. Nutr Hosp. 23:12-19.

Lories, R. J. (2006). Animal models of spondyloarthritis. Curr Opin Rheumatol. 18: 342-346.

Macfarlane, G. T. and Macfarlane, S. (2011). Fermentation in the human large intestine: its physiologic consequences and the potential contribution of prebiotics. J Clin Gastroenterol. 45 Suppl: S120-7.

Macfarlane, G. T., Steed, H., and Macfarlane, S. (2008). Bacterial metabolism and health-related effects of galacto-oligosaccharides and other prebiotics. J Appl Microbiol. 104: 305-344. 
Macfarlane, S., Furrie, E., Kennedy, A., Cummings, J. H., and Macfarlane, G. T. (2005). Mucosal bacteria in ulcerative colitis. Br J Nutr. 93 Suppl 1: S67-72.

MacPherson, G., Milling, S., Yrlid, U., Cousins, L., Turnbull, E., and Huang, F. P. (2004). Uptake of antigens from the intestine by dendritic cells. Ann N Y Acad Sci. 1029:75-82.

Marteau, P., Jacobs, H., Cazaubiel, M., Signoret, C., Prevel, J. M., and Housez, B. (2011). Effects of chicory inulin in constipated elderly people: a double-blind controlled trial. Int J Food Sci Nutr. 62: 164-170.

Maslowski, K. M., Vieira, A. T., Ng, A., Kranich, J., Sierro, F., Yu, D., Schilter, H. C., Rolph, M. S., Mackay, F., Artis, D., Xavier, R. J., Teixeira, M. M., and Mackay, C. R. (2009). Regulation of inflammatory responses by gut microbiota and chemoattractant receptor GPR43. Nature. 461: 1282-1286.

McGlone, J. J. and Fullwood, S. D. (2001). Behavior, reproduction, and immunity of crated pregnant gilts: effects of high dietary fiber and rearing environment. J Anim Sci.79: 1466-1474.

McKernan, D. P., Gaszner, G., Quigley, E. M., Cryan, J. F., and Dinan, T. G. (2011). Altered peripheral toll-like receptor responses in the irritable bowel syndrome. Aliment Pharmacol Ther. 33: $1045-1052$.

McKernan, D. P., Nolan, A., Brint, E. K., O'Mahony, S. M., Hyland, N. P., Cryan, J. F., and Dinan, T. G. (2009). Toll-like receptor mRNA expression is selectively increased in the colonic mucosa of two animal models relevant to irritable bowel syndrome. PloS One. 4: e8226.

Meijer, K., de Vos, P., and Priebe, M. G. (2010). Butyrate and other short-chain fatty acids as modulators of immunity: what relevance for health? Curr Opin Clin Nutr Metab Care. 13: 715721.

Menne, E., Guggenbuhl, N., and Roberfroid, M. (2000). Fn-type chicory inulin hydrolysate has a prebiotic effect in humans. J Nutr. 130: 1197-1199.

Menrad, K. (2003). Market and marketing of functional food in Europe. J Food Eng. 56: 181188.

Middelbos, I. S., Fastinger, N. D., and Fahey, G. C.,Jr. (2007). Evaluation of fermentable oligosaccharides in diets fed to dogs in comparison to fiber standards. J Anim Sci. 85: 30333044.

Misikangas, M., Pajari, A. M., Paivarinta, E., and Mutanen, M. (2005). Promotion of adenoma growth by dietary inulin is associated with increase in cyclin D1 and decrease in adhesion proteins in Min/+ mice mucosa. $J$ Nutr Biochem. 16: 402-409. 
Misikangas, M., Tanayama, H., Rajakangas, J., Linden, J., Pajari, A. M., and Mutanen, M. (2008). Inulin results in increased levels of beta-catenin and cyclin D1 as the adenomas increase in size from small to large in the Min/+ mouse. Br J Nutr. 99: 963-970.

Mollet, B. and Rowland, I. (2002). Functional foods: at the frontier between food and pharma. Curr Opin Biotechnol. 13: 483-485.

Moreau, N. M., Martin, L. J., Toquet, C. S., Laboisse, C. L., Nguyen, P. G., Siliart, B. S., Dumon, H. J., and Champ, M. M. (2003). Restoration of the integrity of rat caeco-colonic mucosa by resistant starch, but not by fructo-oligosaccharides, in dextran sulfate sodium induced experimental colitis. Br J Nutr. 90: 75-85.

Moro, G., Arslanoglu, S., and Stahl, B. (2006a). Infant formula supplemented with a prebiotic mixture of galacto-oligosaccharides and long chain fructo-oligosaccharides reduces the cumulative incidence of atopic dermatitis in infants at risk. J Pediatr Gastroenterol Nutr. 42: E5.

Moro, G., Arslanoglu, S., Stahl, B., Jelinek, J., Wahn, U., and Boehm, G. (2006b). A mixture of prebiotic oligosaccharides reduces the incidence of atopic dermatitis during the first six months of age. Arch Dis Child. 91: 814-819.

Mowat, A. M. (2003). Anatomical basis of tolerance and immunity to intestinal antigens. Nat Rev Immunol. 3: 331-341.

Munjal, U., Glei, M., Pool-Zobel, B. L., and Scharlau, D. (2009). Fermentation products of inulin-type fructans reduce proliferation and induce apoptosis in human colon tumor cells of different stages of carcinogenesis. Br J Nutr. 102: 663-671.

Murosaki, S., Muroyama, K., Yamamoto, Y., Kusaka, H., Liu, T., and Yoshikai, Y. (1999). Immunopotentiating activity of nigerooligosaccharides for the $\mathrm{T}$ helper 1-like immune response in mice. Biosci Biotechnol Biochem. 63: 373-378.

Nakamura, Y., Nosaka, S., Suzuki, M., Nagafuchi, S., Takahashi, T., Yajima, T., TakenouchiOhkubo, N., Iwase, T., and Moro, I. (2004). Dietary fructooligosaccharides up-regulate immunoglobulin A response and polymeric immunoglobulin receptor expression in intestines of infant mice. Clin Exp Immunol. 137: 52-58.

Neal, K. R., Hebden, J., and Spiller, R. (1997). Prevalence of gastrointestinal symptoms six months after bacterial gastroenteritis and risk factors for development of the irritable bowel syndrome: postal survey of patients. BMJ. 314: 779-782.

Newberry, R. D. and Lorenz, R. G. (2005). Organizing a mucosal defense. Immunol Rev.206: 621.

Niess, J. H., Brand, S., Gu, X., Landsman, L., Jung, S., McCormick, B. A., Vyas, J. M., Boes, M., Ploegh, H. L., Fox, J. G., Littman, D. R., and Reinecker, H. C. (2005). CX3CR1-mediated dendritic cell access to the intestinal lumen and bacterial clearance. Science. 307: 254-258. 
Olesen, M. and Gudmand-Hoyer, E. (2000). Efficacy, safety, and tolerability of fructooligosaccharides in the treatment of irritable bowel syndrome. Am J Clin Nutr. 72: 15701575 .

Olguin, F., Araya, M., Hirsch, S., Brunser, O., Ayala, V., Rivera, R., and Gotteland, M. (2005). Prebiotic ingestion does not improve gastrointestinal barrier function in burn patients. Burns. 31: $482-488$.

O'Malley, D., Liston, M., Hyland, N. P., Dinan, T.G., and Cryan, J. F. (2011). Colonic soluble mediators from the maternal separation model of irritable bowel syndrome activate submucosal neurons via an interleukin-6-dependent mechanism. Am J Physiol Gastrointest Liver Physiol. 300: G241-52.

Osman, N., Adawi, D., Molin, G., Ahrne, S., Berggren, A., and Jeppsson, B. (2006). Bifidobacterium infantis strains with and without a combination of oligofructose and inulin (OFI) attenuate inflammation in DSS-induced colitis in rats. BMC Gastroenterol.6: 31.

Osorio, F. and Reis e Sousa, C. (2011). Myeloid C-type lectin receptors in pathogen recognition and host defense. Immunity. 34: 651-664.

Paineau, D., Payen, F., Panserieu, S., Coulombier, G., Sobaszek, A., Lartigau, I., Brabet, M., Galmiche, J. P., Tripodi, D., Sacher-Huvelin, S., Chapalain, V., Zourabichvili, O., Respondek, F., Wagner, A., and Bornet, F. R. (2008). The effects of regular consumption of short-chain fructo-oligosaccharides on digestive comfort of subjects with minor functional bowel disorders. Br J Nutr. 99: 311-318.

Pajari, A. M., Rajakangas, J., Paivarinta, E., Kosma, V. M., Rafter, J., and Mutanen, M. (2003). Promotion of intestinal tumor formation by inulin is associated with an accumulation of cytosolic beta-catenin in Min mice. Int J Cancer. 106: 653-660.

Parnell, J. A. and Reimer, R. A. (2010). Effect of prebiotic fibre supplementation on hepatic gene expression and serum lipids: a dose-response study in JCR:LA-cp rats. Br J Nutr. 103: 15771584.

Pasare, C. and Medzhitov, R. (2005). Control of B-cell responses by Toll-like receptors. Nature. 438: $364-368$.

Pedersen, A., Sandstrom, B., and Van Amelsvoort, J. M. (1997). The effect of ingestion of inulin on blood lipids and gastrointestinal symptoms in healthy females. Br J Nutr. 78:215-222.

Perez, N., Iannicelli, J. C., Girard-Bosch, C., Gonzalez, S., Varea, A., Disalvo, L., Apezteguia, M., Pernas, J., Vicentin, D., and Cravero, R. (2010). Effect of probiotic supplementation on immunoglobulins, isoagglutinins and antibody response in children of low socio-economic status. Eur J Nutr. 49: 173-179. 
Petkevicius, S., Bach Knudsen, K. E., Murrell, K. D., and Wachmann, H. (2003). The effect of inulin and sugar beet fibre on oesophagostomum dentatum infection in pigs. Parasitology. 127: 61-68.

Petkevicius, S., Thomsen, L. E., Bach Knudsen, K. E., Murrell, K. D., Roepstorff, A., and Boes, J. (2007). The effect of inulin on new and on patent infections of Trichuris suis in growing pigs. Parasitology. 134: 121-127.

Podolsky, D. K. (2002). Inflammatory bowel disease. N Engl J Med. 347: 417-429.

Pool-Zobel, B., van Loo, J., Rowland, I., and Roberfroid, M. B. (2002). Experimental evidences on the potential of prebiotic fructans to reduce the risk of colon cancer. Br J Nutr. 87 Suppl 2 : S273-81.

Poulsen, M., Molck, A. M., and Jacobsen, B. L. (2002). Different effects of short- and longchained fructans on large intestinal physiology and carcinogen-induced aberrant crypt foci in rats. Nutr Cancer. 42: 194-205.

Raes, M., Scholtens, P. A., Alliet, P., Hensen, K., Jongen, H., Boehm, G., Vandenplas, Y., and Rummens, J. L. (2010). Exploration of basal immune parameters in healthy infants receiving an infant milk formula supplemented with prebiotics. Pediatr Allergy Immunol. 21: e377-85.

Rafter, J., Bennett, M., Caderni, G., Clune, Y., Hughes, R., Karlsson, P. C., Klinder, A., O'Riordan, M., O'Sullivan, G. C., Pool-Zobel, B., Rechkemmer, G., Roller, M., Rowland, I., Salvadori, M., Thijs, H., Van Loo, J., Watzl, B., and Collins, J. K. (2007). Dietary synbiotics reduce cancer risk factors in polypectomized and colon cancer patients. Am J Clin Nutr. 85: 488496.

Ramiro-Puig, E., Perez-Cano, F. J., Castellote, C., Franch, A., and Castell, M. (2008). The bowel: a key component of the immune system. Rev Esp Enferm Dig. 100: 29-34.

Rao, C. V., Chou, D., Simi, B., Ku, H., and Reddy, B. S. (1998). Prevention of colonic aberrant crypt foci and modulation of large bowel microbial activity by dietary coffee fiber, inulin and pectin. Carcinogenesis. 19: 1815-1819.

Rath, H. C., Schultz, M., Freitag, R., Dieleman, L. A., Li, F., Linde, H. J., Scholmerich, J., and Sartor, R. B. (2001). Different subsets of enteric bacteria induce and perpetuate experimental colitis in rats and mice. Infect Immun. 69: 2277-2285.

Reddy, B. S. (1998). Prevention of colon cancer by pre- and probiotics: evidence from laboratory studies. Br J Nutr. 80: S219-23.

Reddy, B. S., Hamid, R., and Rao, C. V. (1997). Effect of dietary oligofructose and inulin on colonic preneoplastic aberrant crypt foci inhibition. Carcinogenesis. 18: 1371-1374. 
Reddy, B. S., Macfie, J., Gatt, M., Larsen, C. N., Jensen, S. S., and Leser, T. D. (2007). Randomized clinical trial of effect of synbiotics, neomycin and mechanical bowel preparation on intestinal barrier function in patients undergoing colectomy. Br J Surg. 94: 546-554.

Rijnierse, A., Jeurink, P. V., Garssen, J., and Knippels, L. M. (2011). Food-derived oligosaccharides exhibit pharmaceutical properties. Eur J Pharmacol.

Roberfroid, M., Gibson, G. R., Hoyles, L., McCartney, A. L., Rastall, R., Rowland, I., Wolvers, D., Watzl, B., Szajewska, H., Stahl, B., Guarner, F., Respondek, F., Whelan, K., Coxam, V., Davicco, M. J., Leotoing, L., Wittrant, Y., Delzenne, N. M., Cani, P. D., Neyrinck, A. M., and Meheust, A. (2010). Prebiotic effects: metabolic and health benefits. Br J Nutr. 104 Suppl 2: S163.

Roberfroid, M. B. (2007). Inulin-type fructans: functional food ingredients. J Nutr. 137: 2493S$2502 \mathrm{~S}$.

Roberfroid, M. B. (2005). Introducing inulin-type fructans. Br J Nutr. 93 Suppl 1: S13-25.

Roberfroid, M. B. (1999). Concepts in functional foods: the case of inulin and oligofructose. $J$ Nutr. 129: 1398S-401S.

Roller, M., Clune, Y., Collins, K., Rechkemmer, G., and Watzl, B. (2007). Consumption of prebiotic inulin enriched with oligofructose in combination with the probiotics Lactobacillus rhamnosus and Bifidobacterium lactis has minor effects on selected immune parameters in polypectomised and colon cancer patients. Br J Nutr. 97: 676-684.

Roller, M., Pietro Femia, A., Caderni, G., Rechkemmer, G., and Watzl, B. (2004a). Intestinal immunity of rats with colon cancer is modulated by oligofructose-enriched inulin combined with Lactobacillus rhamnosus and Bifidobacterium lactis. Br J Nutr. 92: 931-938.

Roller, M., Rechkemmer, G., and Watzl, B. (2004b). Prebiotic inulin enriched with oligofructose in combination with the probiotics Lactobacillus rhamnosus and Bifidobacterium lactis modulates intestinal immune functions in rats. $J$ Nutr. 134: 153-156.

Rossi, M., Corradini, C., Amaretti, A., Nicolini, M., Pompei, A., Zanoni, S., and Matteuzzi, D. (2005). Fermentation of fructooligosaccharides and inulin by bifidobacteria: a comparative study of pure and fecal cultures. Appl Environ Microbiol. 71: 6150-6158.

Rowland, I. R., Rumney, C. J., Coutts, J. T., and Lievense, L. C. (1998). Effect of Bifidobacterium longum and inulin on gut bacterial metabolism and carcinogen-induced aberrant crypt foci in rats. Carcinogenesis. 19: 281-285.

Rumessen, J. J., Bode, S., Hamberg, O., and Gudmand-Hoyer, E. (1990). Fructans of Jerusalem artichokes: intestinal transport, absorption, fermentation, and influence on blood glucose, insulin, and C-peptide responses in healthy subjects. Am J Clin Nutr. 52: 675-681. 
Schiffrin, E. J., Thomas, D. R., Kumar, V. B., Brown, C., Hager, C., Van't Hof, M. A., Morley, J. E., and Guigoz, Y. (2007). Systemic inflammatory markers in older persons: the effect of oral nutritional supplementation with prebiotics. J Nutr Health Aging. 11:475-479.

Scholtens, P. A., Alliet, P., Raes, M., Alles, M. S., Kroes, H., Boehm, G., Knippels, L. M., Knol, J., and Vandenplas, Y. (2008). Fecal secretory immunoglobulin A is increased in healthy infants who receive a formula with short-chain galacto-oligosaccharides and long-chain fructooligosaccharides. J Nutr. 138: 1141-1147.

Schouten, B., van Esch, B. C., Hofman, G. A., van Doorn, S. A., Knol, J., Nauta, A. J., Garssen, J., Willemsen, L. E., and Knippels, L. M. (2009). Cow milk allergy symptoms are reduced in mice fed dietary synbiotics during oral sensitization with whey. J Nutr. 139: 1398-1403.

Schouten, B., Van Esch, B. C., Kormelink, T. G., Moro, G. E., Arslanoglu, S., Boehm, G., Knippels, L. M., Redegeld, F. A., Willemsen, L. E., and Garssen, J. (2011). Non digestible oligosaccharides reduce immunoglobulin free light-chain concentrations in infants at risk for allergy. Pediatr Allergy Immunol. 22: 537-542.

Schultz, M., Munro, K., Tannock, G. W., Melchner, I., Gottl, C., Schwietz, H., Scholmerich, J., and Rath, H. C. (2004). Effects of feeding a probiotic preparation (SIM) containing inulin on the severity of colitis and on the composition of the intestinal microflora in HLA-B27 transgenic rats. Clin Diagn Lab Immunol. 11: 581-587.

Seidel, C., Boehm, V., Vogelsang, H., Wagner, A., Persin, C., Glei, M., Pool-Zobel, B. L., and Jahreis, G. (2007). Influence of prebiotics and antioxidants in bread on the immune system, antioxidative status and antioxidative capacity in male smokers and non smokers. Br J Nutr. 97: 349-356.

Seifert, S. and Watzl, B. (2007). Inulin and oligofructose: review of experimental data on immune modulation. J Nutr. 137: 2563S-2567S.

Sembries, S., Dongowski, G., Jacobasch, G., Mehrlander, K., Will, F., and Dietrich, H. (2003). Effects of dietary fibre-rich juice colloids from apple pomace extraction juices on intestinal fermentation products and microbiota in rats. Br J Nutr. 90: 607-615.

Shadid, R., Haarman, M., Knol, J., Theis, W., Beermann, C., Rjosk-Dendorfer, D., Schendel, D. J., Koletzko, B. V., and Krauss-Etschmann, S. (2007). Effects of galactooligosaccharide and long-chain fructooligosaccharide supplementation during pregnancy on maternal and neonatal microbiota and immunity--a randomized, double blind, placebo-controlled study. Am J Clin Nutr. 86: 1426-1437.

Shim, S. B., Verstegen, M. W., Kim, I. H., Kwon, O. S., and Verdonk, J. M. (2005). Effects of feeding antibiotic-free creep feed supplemented with oligofructose, probiotics or synbiotics to suckling piglets increases the preweaning weight gain and composition of intestinal microbiota. Arch Anim Nutr. 59: 419-427. 
Smith, C. L., Geier, M. S., Yazbeck, R., Torres, D. M., Butler, R. N., and Howarth, G. S. (2008). Lactobacillus fermentum BR11 and fructo-oligosaccharide partially reduce jejunal inflammation in a model of intestinal mucositis in rats. Nutr Cancer. 60: 757-767.

Spahn, T. W. and Kucharzik, T. (2004). Modulating the intestinal immune system: the role of lymphotoxin and GALT organs. Gut. 53: 456-465.

Spiller, R. C., Jenkins, D., Thornley, J. P., Hebden, J. M., Wright, T., Skinner, M., and Neal, K. R. (2000). Increased rectal mucosal enteroendocrine cells, T lymphocytes, and increased gut permeability following acute Campylobacter enteritis and in post dysenteric irritable bowel syndrome. Gut. 47: 804-811.

Stewart, M. L., Timm, D. A., and Slavin, J. L. (2008). Fructooligosaccharides exhibit more rapid fermentation than long-chain inulin in an in vitro fermentation system. Nutr Res. 28: 329-334.

Stillie, R., Bell, R. C., and Field, C. J. (2005). Diabetes-prone BioBreeding rats do not have a normal immune response when weaned to a diet containing fermentable fibre. Br J Nutr. 93: 645-653.

Strober, W., Fuss, I., and Mannon, P. (2007). The fundamental basis of inflammatory bowel disease. J Clin Invest. 117: 514-521.

Swanson, K. S., Grieshop, C. M., Flickinger, E. A., Healy, H. P., Dawson, K. A., Merchen, N. R., and Fahey, G. C.,Jr. (2002). Effects of supplemental fructooligosaccharides plus mannanoligosaccharides on immune function and ileal and fecal microbial populations in adult dogs. Arch Tierernahr. 56: 309-318.

Taper, H. S., Delzenne, N. M., and Roberfroid, M. B. (1997). Growth inhibition of transplantable mouse tumors by non-digestible carbohydrates. Int J Cancer. 71: 1109-1112.

Taper, H. S., Lemort, C., and Roberfroid, M. B. (1998). Inhibition effect of dietary inulin and oligofructose on the growth of transplantable mouse tumor. Anticancer Res. 18: 4123-4126.

Taper, H. S. and Roberfroid, M. (1999). Influence of inulin and oligofructose on breast cancer and tumor growth. J Nutr. 129: 1488S-91S.

Taper, H. S. and Roberfroid, M. B. (2005). Possible adjuvant cancer therapy by two prebiotics-inulin or oligofructose. In Vivo. 19: 201-204.

Taper, H. S. and Roberfroid, M. B. (2002). Non-toxic potentiation of cancer radiotherapy by dietary oligofructose or inulin. Anticancer Res. 22: 3319-3323.

Taper, H. S. and Roberfroid, M. B. (2000a). Inhibitory effect of dietary inulin or oligofructose on the development of cancer metastases. Anticancer Res. 20: 4291-4294. 
Taper, H. S. and Roberfroid, M. B. (2000b). Nontoxic potentiation of cancer chemotherapy by dietary oligofructose or inulin. Nutr Cancer. 38: 1-5.

Thomsen, L. E., Petkevicius, S., Bach Knudsen, K. E., and Roepstorff, A. (2005). The influence of dietary carbohydrates on experimental infection with Trichuris suis in pigs. Parasitology. 131: 857-865.

Tornblom, H., Lindberg, G., Nyberg, B., and Veress, B. (2002). Full-thickness biopsy of the jejunum reveals inflammation and enteric neuropathy in irritable bowel syndrome. Gastroenterology. 123: 1972-1979.

Travis, S. (2006). Review article: saving the colon in severe colitis - the case for medical therapy. Aliment Pharmacol Ther. 24 Suppl 3: 68-73.

Trifari, S., Kaplan, C. D., Tran, E. H., Crellin, N. K., and Spits, H. (2009). Identification of a human helper $\mathrm{T}$ cell population that has abundant production of interleukin 22 and is distinct from $\mathrm{T}(\mathrm{H})-17, \mathrm{~T}(\mathrm{H}) 1$ and $\mathrm{T}(\mathrm{H}) 2$ cells. Nat Immunol. 10: 864-871.

Trushina, E. N., Martynova, E. A., Nikitiuk, D. B., Mustafina, O. K., and Baigarin, E. K. (2005). The influence of dietary inulin and oligofructose on the cell-mediated andhumoral immunity in rats. Vopr Pitan. 74: 22-27.

van de Wiele, T., Boon, N., Possemiers, S., Jacobs, H., and Verstraete, W. (2007). Inulin type fructans of longer degree of polymerization exert more pronounced in vitro prebiotic effects. $J$ Appl Microbiol. 102: 452-460.

van der Horst, H. E., Jellema, P., van der Windt, D. A., and Schellevis, F. G. (2010). Irritable bowel syndrome: criteria and clinical view. Ned Tijdschr Geneeskd. 154: A1871.

van Hoffen, E., Ruiter, B., Faber, J., M'Rabet, L., Knol, E. F., Stahl, B., Arslanoglu, S., Moro, G., Boehm, G., and Garssen, J. (2009). A specific mixture of short-chain galacto oligosaccharides and long-chain fructo-oligosaccharides induces a beneficial immunoglobulin profile in infants at high risk for allergy. Allergy. 64: 484-487.

Veldhoen, M., Uyttenhove, C., van Snick, J., Helmby, H., Westendorf, A., Buer, J., Martin, B., Wilhelm, C., and Stockinger, B. (2008). Transforming growth factor-beta 'reprograms' the differentiation of T helper 2 cells and promotes an interleukin 9- producing subset. Nat Immunol. 9: 1341-1346.

Vereyken, I. J., Chupin, V., Hoekstra, F. A., Smeekens, S. C., and de Kruijff, B. (2003a). The effect of fructan on membrane lipid organization and dynamics in the dry state. Biophys J. 84: 3759-3766.

Vereyken, I. J., Chupin, V., Islamov, A., Kuklin, A ., Hincha, D. K., and de Kruijff, B. (2003b). The effect of fructan on the phospholipid organization in the dry state. Biophys J. 85: 3058-3065. 
Vereyken, I. J., van Kuik, J. A., Evers, T. H., Rijken, P. J., and de Kruijff, B. (2003c). Structural requirements of the fructan-lipid interaction. Biophys J. 84: 3147-3154.

Verghese, M., Rao, D. R., Chawan, C. B., and Shackelford, L. (2002a). Dietary inulin suppresses azoxymethane-induced preneoplastic aberrant crypt foci in mature Fisher 344 rats. $J$ Nutr. 132: 2804-2808.

Verghese, M., Rao, D. R., Chawan, C. B., Williams, L. L., and Shackelford, L. (2002b). Dietary inulin suppresses azoxymethane-induced aberrant crypt foci and colon tumors at the promotion stage in young Fisher 344 rats. J Nutr. 132: 2809-2813.

Verlinden, A., Hesta, M., Hermans, J. M., and Janssens, G. P. (2006). The effects of inulin supplementation of diets with or without hydrolysed protein sources on digestibility, faecal characteristics, haematology and immunoglobulins in dogs. Br J Nutr. 96: 936-944.

Videla, S., Vilaseca, J., Antolin, M., Garcia-Lafuente, A., Guarner, F., Crespo, E., Casalots, J., Salas, A., and Malagelada, J. R. (2001). Dietary inulin improves distal colitis induced by dextran sodium sulfate in the rat. Am J Gastroenterol. 96: 1486-1493.

Vos, A. P., Haarman, M., Buco, A., Govers, M., Knol, J., Garssen, J., Stahl, B., Boehm, G., and M'Rabet, L. (2006). A specific prebiotic oligosaccharide mixture stimulates delayed-type hypersensitivity in a murine influenza vaccination model. Int Immunopharmacol. 6: 1277-1286.

Vos, A. P., Haarman, M., van Ginkel, J. W., Knol, J., Garssen, J., Stahl, B., Boehm, G., and M'Rabet, L. (2007a). Dietary supplementation of neutral and acidic oligosaccharides enhances Th1-dependent vaccination responses in mice. Pediatr Allergy Immunol. 18: 304-312.

Vos, A. P., M'Rabet, L., Stahl, B., Boehm, G., and Garssen, J. (2007b). Immune modulatory effects and potential working mechanisms of orally applied nondigestible carbohydrates. Crit Rev Immunol. 27: 97-140.

Vulevic, J., Drakoularakou, A., Yaqoob, P., Tzortzis, G., and Gibson, G. R. (2008). Modulation of the fecal microflora profile and immune function by a novel trans galactooligosaccharide mixture (B-GOS) in healthy elderly volunteers. Am J Clin Nutr. 88: 1438-1446.

Waligora-Dupriet, A. J., Campeotto, F., Nicolis, I., Bonet, A., Soulaines, P., Dupont, C., and Butel, M. J. (2007). Effect of oligofructose supplementation on gut microflora and well-being in young children attending a day care centre. Int J Food Microbiol. 113: 108-113.

Welters, C. F., Heineman, E., Thunnissen, F. B., van den Bogaard, A. E., Soeters, P. B.,and Baeten, C. G. (2002). Effect of dietary inulin supplementation on inflammation of pouch mucosa in patients with an ileal pouch-anal anastomosis. Dis Colon Rectum. 45:621-627.

Whelan, K. (2011). Probiotics and prebiotics in the management of irritable bowel syndrome: a review of recent clinical trials and systematic reviews. Curr Opin Clin Nutr Metab Care. 14: 581-587. 
Winkler, J., Butler, R., and Symonds, E. (2007). Fructo-oligosaccharide reduces inflammation in a dextran sodium sulphate mouse model of colitis. Dig Dis Sci. 52: 52-58.

Wong, J. M., de Souza, R., Kendall, C. W., Emam, A., and Jenkins, D. J. (2006). Colonic health: fermentation and short chain fatty acids. J Clin Gastroenterol. 40: 235-243.

Wouters, M. M. and Boeckxstaens, G. E. (2011). Neuroimmune mechanisms in functional bowel disorders. Neth J Med. 69: 55-61.

Wu, G. D., Wang, W., and Traber, P. G. (1992). Isolation and characterization of the human sucrase-isomaltase gene and demonstration of intestine-specific transcriptional elements. J Biol Chem. 267: 7863-7870.

Xavier, R. J. and Podolsky, D. K. (2007). Unravelling the pathogenesis of inflammatory bowel disease. Nature. 448: 427-434.

Yeh, S. L., Lin, M. S., and Chen, H. L. (2007). Inhibitory effects of a soluble dietary fiber from Amorphophallus konjac on cytotoxicity and DNA damage induced by fecal water in Caco-2 cells. Planta Med. 73: 1384-1388. 
Table 1. Effects of inulin-type fructans from chicory on immune function in healthy experimental animal models.

\begin{tabular}{|c|c|c|c|}
\hline REF. & $\begin{array}{l}\text { Fructans used } \\
\text { (concentration) }\end{array}$ & $\begin{array}{c}\text { Study design, duration, number } \\
\text { of subjects }\end{array}$ & Results \\
\hline $\begin{array}{l}\text { Swanson et } \\
\text { al. 2002a. }\end{array}$ & FOS + MOS $(2 / 1 \mathrm{~g} / \mathrm{d})$ & Dogs, $14 \mathrm{~d}, \mathrm{n}=8$, via gelatin capsule & $\begin{array}{l}\text { Lowered blood neutrophils, increased blood } \\
\text { lymphocytes vs placebo }\end{array}$ \\
\hline $\begin{array}{l}\text { Swanson et } \\
\text { al. 2002b. }\end{array}$ & $\begin{array}{l}\text { FOS and/or Mannose } \\
\text { oligosaccharide (MOS, 1/1 } \\
\text { g/d) }\end{array}$ & Dogs, $14 \mathrm{~d}, \mathrm{n}=4$, ileal canulas & $\begin{array}{l}\text { Ileal \& serum IgA increased, increased \% blood } \\
\text { lymphocytes }\end{array}$ \\
\hline $\begin{array}{l}\text { Hosono et } \\
\text { al. } 2003 \text {. }\end{array}$ & FOS $(0-7.5 \%)$ & $\begin{array}{l}\text { BALB/c Mice, } 6 \mathrm{wk}, \mathrm{n}=7 \text {, oral } \\
\text { admin. }\end{array}$ & $\begin{array}{l}\text { fecal IgA increased, IgA secretion by Peyer's patch } \\
\text { (PP) cells upregulated, CD4+ T cells from PP } \\
\text { showed increased IL-10 and IFN- } \gamma \text {, IL-5 and IL-6. } \\
\text { Suppressed serum IgG1 }\end{array}$ \\
\hline $\begin{array}{l}\text { Kelly- } \\
\text { Quagliana } \\
\text { et al. } 2003 \text {. }\end{array}$ & $\begin{array}{l}\text { Cellulose, cellulose/OF, OF or } \\
\text { inulin }(10 \%)\end{array}$ & Mice, $6 \mathrm{wk}, \mathrm{n}=8$, diet ad lib. & $\begin{array}{l}\text { Decreased leukocyte counts with inulin and OF, } \\
\text { increased macrophage phagocytosis, increased NK } \\
\text { activity of spleen cells. No effects on fecal IgA or on } \\
\text { lymphocyte subsets in spleen and thymus }\end{array}$ \\
\hline $\begin{array}{l}\text { Nakamura } \\
\text { et al. } 2004 .\end{array}$ & FOS $(5 \%)$ & Infant $\mathrm{BALB} / \mathrm{c}$ mice, $38 \mathrm{~d}, \mathrm{n}=4$ & $\begin{array}{l}\text { IgA in gut tissue extracts and ileal IgA secretion rate } \\
\text { increased, increased polymeric immunoglobulin } \\
\text { receptor (pIgR) expression, increased } \% \text { of } \\
\mathrm{B} 220(+) \operatorname{Ig} \mathrm{A}+\text { cells in PP }\end{array}$ \\
\hline $\begin{array}{l}\text { Roller et al. } \\
2004 \mathrm{~b} .\end{array}$ & OF/inulin $(1 / 1,10 \%)$ & $\begin{array}{l}\text { Rats, } 4 \text { wk, } n=80 \text {, suppl to high fat } \\
\text { diet }\end{array}$ & $\begin{array}{l}\text { Higher production of IL-10 and IFN- } \gamma \text { in PP, no } \\
\text { effect on NK activity, lymphocyte proliferation and } \\
\text { cytokine production in spleen MLN and PP }\end{array}$ \\
\hline $\begin{array}{l}\text { Shim et al. } \\
2005 \text {. }\end{array}$ & $\begin{array}{l}\text { OF }(0,2 \%), \text { syn: OF-PRO } \\
(0,2 / 0,3 \%)\end{array}$ & $\begin{array}{l}\text { Suckling piglets, } 21 \mathrm{~d}, \mathrm{n}=50 \text {, diet } \\
\text { ad lib. }\end{array}$ & \% Lymphocytes and neutrophils in blood unaltered \\
\hline $\begin{array}{l}\text { Trushina et } \\
\text { al. } 2005 \text {. }\end{array}$ & FOS, inulin (10\%) & $\begin{array}{l}\text { Rats, } 4 \mathrm{mo}, \mathrm{n}=\mathrm{nd}, \quad \text { isocaloric } \\
\text { purified diets containing } \\
\text { supplement of OF or inulin }\end{array}$ & $\begin{array}{l}\text { Increased number of T cells in spleen, MLN and } \\
\text { thymus, level of IL-4 in blood. No effect on immune } \\
\text { apoptosis }\end{array}$ \\
\hline $\begin{array}{l}\text { Verlinden } \\
\text { et al. } 2006 .\end{array}$ & Inulin 3\% & $\begin{array}{l}\text { Dogs, 26d, } n=4 \text {, supplementation } \\
\text { to basal diet }\end{array}$ & $\begin{array}{l}\text { No effect on serum IgA, IgE, IgG and IgM, or on } \\
\text { fecal } \operatorname{Ig} \mathrm{A}\end{array}$ \\
\hline $\begin{array}{l}\text { Cerezuela } \\
\text { et al. } 2008 .\end{array}$ & Inulin $(0,5$ or $1 \%)$ & $\begin{array}{l}\text { Seabream, } 1 \mathrm{wk}, \mathrm{n}=45 \text {, suppl. to } \\
\text { commercial diet }\end{array}$ & $\begin{array}{l}\text { Inhibition of phagocytosis and respiratory burst in } \\
\text { leucocytes }\end{array}$ \\
\hline
\end{tabular}




\section{Critical Reviews in Food Science and Nutrition}

\begin{tabular}{|c|c|c|c|}
\hline $\begin{array}{l}\text { Janardhana } \\
\text { et al. } 2009 .\end{array}$ & FOS or MOS $(5 \mathrm{~g} / \mathrm{kg})$ & $\begin{array}{l}\text { Chickens, } 25 \mathrm{~d}, \mathrm{n}=125 \text {, add.to basal } \\
\text { diet }\end{array}$ & $\begin{array}{l}\text { Reduced proportion of B cells and mitogen } \\
\text { responsiveness of lymphocytes in Cecal Tonsil, } \\
\text { enhanced plasma IgM and IgG }\end{array}$ \\
\hline $\begin{array}{l}\text { Yasuda et } \\
\text { al. } 2009 \text {. }\end{array}$ & FOS, inulin, FOS/inulin (4\%) & $\begin{array}{l}\text { Pigs, 7wk, suppl. To corn/soybean } \\
\text { basal meal }\end{array}$ & $\begin{array}{l}\text { Decreased expression of inflammation related genes } \\
\text { especially in lower gut mucosa }\end{array}$ \\
\hline
\end{tabular}

Abbreviations: FOS - Fructooligosaccharides, MOS - Mannose oligosaccharide, Ig - Immunoglobulin, OF -

Oligofructose, PP - Peyer's patches, IL - Interleukin, IFN - Interferon, SYN - Synbiotic, PRO - Probiotic, Ad lib Ad libitum, MLN - Mesenteric lymph nodes 
Table 2. Immunological parameters in experimental animal cancer models and human cancer patients.

\begin{tabular}{|c|c|c|c|}
\hline REF. & $\begin{array}{l}\text { Fructans used } \\
\text { (concentration) }\end{array}$ & $\begin{array}{l}\text { Study design, duration, } \\
\text { number of subjects }\end{array}$ & Results \\
\hline \multicolumn{4}{|c|}{ Studies in experimental animals } \\
\hline $\begin{array}{l}\text { Roller et al. } \\
\text { 2004b. }\end{array}$ & $\begin{array}{l}\text { PRE,: inulin enriched } \\
\text { with FOS, } 100 \mathrm{~g} / \mathrm{kg} \\
\text { PRO: LGG + BB12 } \\
\text { SYN: PRE + PRO }\end{array}$ & $\begin{array}{l}\text { Cancer model rats, } 33 \mathrm{wk}, \\
\mathrm{n}=32,33,32\end{array}$ & $\begin{array}{l}\text { Restored NK cell-like cytotoxicity in PP, } \\
\text { Increased IL-10 production in GALT } \\
\text { Decreased PP IFN- } \gamma \text { production } \\
\text { Suppression of lymphocytes PP proliferative } \\
\text { responsiveness }\end{array}$ \\
\hline $\begin{array}{l}\text { Forest et al. } \\
2005 \text {. }\end{array}$ & FOS (sc-FOS, 5,8\%) & $\begin{array}{l}\text { Apc+/Min mice Cancer model, } \\
\mathrm{n}=12 \text {, diet ad lib. }\end{array}$ & $\begin{array}{l}\text { Decreased nr of CD25+ LI-IELs, Increased nrs of IL- } \\
\text { 15+/IL-15R } \alpha+\text { IELS } \\
\text { Increase in CD69+cells } \\
\text { Decreased CD4+ CD25+ LI-IELs }\end{array}$ \\
\hline \multicolumn{4}{|c|}{ Studies in humans } \\
\hline $\begin{array}{l}\text { Rafter et al. } \\
2007 .\end{array}$ & $\begin{array}{l}\text { SYN: FOS-enriched } \\
\text { inulin }(10 \mathrm{~g})(\mathrm{SYN} 1)+ \\
\text { (LGG and BB12 }\end{array}$ & $\begin{array}{l}\text { Human cancer, } \\
\text { polyp-ectomized patients } \\
\mathrm{P}, \mathrm{RCT}, \mathrm{DB}, \mathrm{n}=80,12 \mathrm{wk}\end{array}$ & $\begin{array}{l}\text { SYN prevented an increased secretion of IL- } 2 \text { by } \\
\text { PBMCs in the polypectomized patients and increased } \\
\text { the production of IFN-gamma in the cancer patients. } \\
\text { Other immunity-related parameters were not affected } \\
\text { by SYN treatment }\end{array}$ \\
\hline $\begin{array}{l}\text { Reddy et al. } \\
2007 .\end{array}$ & $\begin{array}{l}\text { SYN: FOS }+B \text {. } \\
\text { longatum }\end{array}$ & $\begin{array}{l}\text { Human Colonectomy patients } \\
\mathrm{n}=64\end{array}$ & $\begin{array}{l}\text { Significantly lower incidence of translocation, no } \\
\text { change in intestinal permeability, inflammatory } \\
\text { response or septic morbidity }\end{array}$ \\
\hline $\begin{array}{l}\text { Roller et al. } \\
2007 .\end{array}$ & $\begin{array}{l}\text { SYN: FOS-enriched } \\
\text { inulin }(10 \mathrm{~g})(\mathrm{SYN} 1)+ \\
\text { LGG and BB12 }\end{array}$ & $\begin{array}{l}\text { Colon cancer patients and } \\
\text { polyp-ectomized patients } 12 \text { - } \\
\text { wk, P, RCT, DB, n=74 }\end{array}$ & $\begin{array}{l}\text { IL-2 secretion by activated PBMC from the polyp } \\
\text { group increased. In the cancer group, SYN treatment } \\
\text { resulted in an increased capacity of PBMC to produce } \\
\text { IFN-gamma. Other immunity-related parameters were } \\
\text { not affected by SYN treatment. }\end{array}$ \\
\hline
\end{tabular}

Abbreviations: FOS - Fructooligosaccharides, PP - Peyer's patches, IL - Interleukin, IFN - Interferon, SYN Synbiotic, PRO - Probiotic, Ad lib - Ad libitum, PRE - Prebiotic, GALT - Gut associated lymphoid tissue, NK Natural killer, Sc - Short chain, Apc+/Min - adenomatous polyposis coli /multiple intestinal neoplasia, LI-IEL Large intestinal intraepithelial lymphocytes, LGG - Lactobacillus rhamnosus GG, BB12 - Bifidobacterium lactis 


\section{Critical Reviews in Food Science and Nutrition}

Bb12, P or PC - Placebo controlled, RCT - Randomized controlled trial, DB - Double blind, PBMC - Peripheral blood mononuclear cell. 
Critical Reviews in Food Science and Nutrition

Table 3. Effects of inulin-type fructans on gastrointestinal inflammation in experimental animals.

\begin{tabular}{|c|c|c|c|}
\hline REF. & Fructans used (concentration) & Animals & Results \\
\hline $\begin{array}{l}\text { Catala et al. } \\
\text { 1999,Butel } \\
\text { et al. } 2002\end{array}$ & $\mathrm{OF}(3 \%)$ & $\begin{array}{l}\text { Quails / inoculation with } \\
\text { clostridia to induce } \\
\text { necrotizing enterocolitis }\end{array}$ & less lesions, less severity of disease index \\
\hline $\begin{array}{l}\text { Videla et al. } \\
2001 .\end{array}$ & $\begin{array}{l}\text { Inulin }(1 \% \text { in drinking water or } \\
400 \mathrm{mg} / \text { day })\end{array}$ & Rats DSS colitis & $\begin{array}{l}\text { Reduced mucosal damage, less inflammatory } \\
\text { mediators released }\end{array}$ \\
\hline $\begin{array}{l}\text { Holma et al. } \\
2002 .\end{array}$ & GOS (4g/kg.day) & Rats TNBS colitis & No reduction of colitis \\
\hline $\begin{array}{l}\text { Cherbut et } \\
\text { al. } 2003 \text {. }\end{array}$ & $1 \mathrm{~g} / \mathrm{d}$ FOS & Rats TNBS colitis & $\begin{array}{l}\text { Reduced the gross score for inflammation, } \\
\text { myeloperoxidase (MPO) activity }\end{array}$ \\
\hline $\begin{array}{l}\text { Moreau et } \\
\text { al. } 2003 \text {. }\end{array}$ & FOS (unspecified) & Rats DSS colitis & No reduction of colitis \\
\hline $\begin{array}{l}\text { Schultz et } \\
\text { al. } 2004 \text {. }\end{array}$ & $\begin{array}{l}\text { Synbiotic: inulin (unspecified) and } \\
\text { L. acidophilus La-5 } \\
\text { and Bifidobacterium lactis Bb }\end{array}$ & $\begin{array}{l}\text { Transgenic rats HLA-B27 } \\
\text { colitis }\end{array}$ & $\begin{array}{l}\text { Colitis reduction (histological score of } \\
\text { Inflammatory cells, ulcer, Goblet cells, crypt } \\
\text { abscess, Mucosa thickening, Submucosa cell } \\
\text { infiltration, destruction of architecture) }\end{array}$ \\
\hline $\begin{array}{l}\text { Hoentjen et } \\
\text { al. } 2005 \text {. }\end{array}$ & $\begin{array}{l}\text { FOS/inulinHP }(1 / 1, \quad 5 \quad \mathrm{~g} / \mathrm{kg} \\
\text { bodyweight via drinking water })\end{array}$ & $\begin{array}{l}\text { Transgenic Rats HLA-B27 } \\
\text { colitis }\end{array}$ & $\begin{array}{l}\text { Reduction of colitis scores, inflammation in } \\
\text { gut mucosa, reduced IL-1 } \beta \text { but increased TGF- } \\
\beta \text { in cecum }\end{array}$ \\
\hline $\begin{array}{l}\text { Daddaoua } \\
\text { et al. } 2006 .\end{array}$ & $\begin{array}{l}\text { Goat milk oligosaccharides } 500 \\
\mathrm{mg} /(\mathrm{kg} . \mathrm{d})\end{array}$ & Rats TNBS colitis & $\begin{array}{l}\text { Colitis reduction: } \\
\text { reduced bowel wall thickening and } \\
\text { longitudinal extension of necrotic lesions; } \\
\text { downregulated colonic expression of IL1 } \beta \text {, } \\
\text { inducible nitric oxide synthase, cox } 2 \text {, and } \\
\text { mucin 3; increased trefoil factor } 3 \text {. }\end{array}$ \\
\hline $\begin{array}{l}\text { Lara- } \\
\text { Villoslada } \\
\text { et al. } 2006 \text {. }\end{array}$ & Goat milk oligosaccharides $5 \%$ & Rats DSS colitis & $\begin{array}{l}\text { Colitis reduction (less colonic } \\
\text { myeloperoxidase activity/ clinical symptoms, } \\
\text { mucin-3 expression return to basal) }\end{array}$ \\
\hline $\begin{array}{l}\text { Osman et } \\
\text { al. } 2006 \text {. }\end{array}$ & OF/inulin $(1 / 1,0,5 \mathrm{~g} / \mathrm{d})$ & Rats DSS colitis & $\begin{array}{l}\text { Lower disease index, reduction colonic IL-1 } \beta \\
\text { less bacterial translocation to MLN } \\
\text { no effect on colonic TGF- } \beta \text { or IL-10 }\end{array}$ \\
\hline
\end{tabular}




\section{Critical Reviews in Food Science and Nutrition}

\begin{tabular}{|l|l|l|l|}
\hline $\begin{array}{l}\text { Apanavicius } \\
\text { et al. 2007. }\end{array}$ & Inulin or FOS, 1\% & $\begin{array}{l}\text { Dogs, 14d, n=10, Salmonella } \\
\text { inoculation }\end{array}$ & $\begin{array}{l}\text { Improved food intake, attenuated enterocyte } \\
\text { sloughing, }\end{array}$ \\
\hline $\begin{array}{l}\text { Bakke- } \\
\text { Mcllep et }\end{array}$ & Inulin (7,5\%) 2007. & $\begin{array}{l}\text { Salmon soybean induced } \\
\text { colitis }\end{array}$ & No effects \\
\hline $\begin{array}{l}\text { Winkler et } \\
\text { al. 2007. }\end{array}$ & FOS 1.5 g/mL & Mouse DSS colitis & Increased crypt depth and area, faster recovery \\
\hline $\begin{array}{l}\text { Smith et al. } \\
2008 .\end{array}$ & FOS (3\%), FOS (6\%), or synbiotic & Rats 5-fluorouracil mucositis & Histological damage increased for every group, \\
(BR11/FOS). & & reduced jejunal inflammation, no effect on \\
\hline Ito et al. & scFOS (DP4-8), 60 g DP4 or DP8 & Rats TNBS colitis & Significantly reduced colonic injuries, bacterial \\
2009. & per kilogram for 7 days & & translocation, increased cecal IgA \\
\hline
\end{tabular}

Abbreviations: FOS - Fructooligosaccharides, Ig - Immunoglobulin, OF - Oligofructose, IL - Interleukin, IFN -

Interferon, SYN - Synbiotic, MLN - Mesenteric lymph nodes, Sc - Short chain, DSS - Dextran sodium sulfate, TNBS - Trinitrobenzenesulphonic acid, GOS - Galactooligosaccharides, DP - Degree of polymerization, GMOS Goat milk oligosaccharides, TGF - Transforming growth factor, BR11 - Lactobacillus fermentum BR11. 
Table 4. Effects of inulin type fructans in human irritable bowel syndrome (IBS) and inflammatory bowel disease (IBD).

\begin{tabular}{|c|c|c|c|c|}
\hline REF. & $\begin{array}{l}\text { Fructans used } \\
\text { (concentration) }\end{array}$ & $\begin{array}{c}\text { Study design, duration, } \\
\text { number of subjects }\end{array}$ & $\begin{array}{c}\text { Target } \\
\text { group / } \\
\text { Condition }\end{array}$ & Results \\
\hline \multicolumn{5}{|c|}{ Studies in adult patients with IBS or constipation } \\
\hline $\begin{array}{l}\text { Hunter et al. } \\
1999 .\end{array}$ & FOS $(6 g / d)$ & $\mathrm{DB}, \mathrm{CO}, 4 \mathrm{wk}, \mathrm{n}=21$ & Adults/IBS & $\begin{array}{l}\text { No effects on symptom } \\
\text { scores }\end{array}$ \\
\hline $\begin{array}{l}\text { Olesen and } \\
\text { Gudmand- } \\
\text { Hoyer. } 2000 .\end{array}$ & FOS $(20 \mathrm{~g} / \mathrm{d})$ & RCT, DB, parallel, $12 \mathrm{wk}, \mathrm{n}=98$ & Adults/IBS & $\begin{array}{l}\text { Greater improvement in } \\
\text { placebo group; no difference } \\
\text { for symptoms at end of } \\
\text { treatment }\end{array}$ \\
\hline $\begin{array}{l}\text { Astegiano et al. } \\
2006 \text {. }\end{array}$ & $\begin{array}{l}\text { Dietary integrator (IBS } \\
\text { Active), } \\
\text { inulin, angelica, vegetal } \\
\text { charcoal, vitamin PP, group } \\
\text { B vitamins (B1, B2, B6), (L. } \\
\text { sporogenes, L.acidophilus, } \\
\text { S.thermophilus, syn }\end{array}$ & $\begin{array}{l}6 \mathrm{mo}, \mathrm{n}=37, \text { control group } \\
\text { without supplementation on } \\
\text { normal treatment }\end{array}$ & Adults/IBS & $\begin{array}{l}\text { Significant reduction in pain } \\
\text { symptoms, abdominal } \\
\text { distension and regulation of } \\
\text { bowel movement in IBS } \\
\text { patients }\end{array}$ \\
\hline $\begin{array}{l}\text { Colecchia et al. } \\
2006 .\end{array}$ & $\begin{array}{l}\text { SYN: } B \text {. longum and FOS } \\
\text { Actilight } 3 \mathrm{~g} / \mathrm{d}\end{array}$ & $\mathrm{N}=636,43$ centers, $36 \mathrm{~d}$ & $\begin{array}{l}\text { adults / } \\
\text { constipation- } \\
\text { IBS }\end{array}$ & $\begin{array}{l}\text { Increased stool frequency } \\
\text { and reduced abdominal pain } \\
\text { and bloating }\end{array}$ \\
\hline $\begin{array}{l}\text { Paineau et al. } \\
2008 \text {. }\end{array}$ & FOS $(5 \mathrm{~g} / \mathrm{d})$ & $\begin{array}{l}\text { Questionnaire digestive } \\
\text { disorders, } \\
6 \mathrm{wk}\end{array}$ & Minor IBS & $\begin{array}{l}\text { Decreased intensity and } \\
\text { incidence of digestive } \\
\text { discomfort }\end{array}$ \\
\hline \multicolumn{5}{|c|}{ Studies in adult patients with pouchitis and/or IBD } \\
\hline $\begin{array}{l}\text { Welters et al. } \\
2002 \text {. }\end{array}$ & Inulin $(24 \mathrm{~g} / \mathrm{d})$ & RCT, DB, CO, 3 wk, n=24 & $\begin{array}{l}\text { Patients/ } \\
\text { Pouchitis }\end{array}$ & $\begin{array}{l}\text { No effect on clinical } \\
\text { symptoms, lower pouchitis } \\
\text { disease index }\end{array}$ \\
\hline $\begin{array}{l}\text { Furrie et al. } \\
2005 .\end{array}$ & $\begin{array}{l}\text { SYN: } 2 \times 1 \text { B. longum } \\
16 \mathrm{~g} / \mathrm{d}\end{array}$ & $\mathrm{DB}, \mathrm{RCT}, \mathrm{n}=18,1 \mathrm{mo}$ & $\begin{array}{l}\text { Adults/ IBD } \\
\text { (UC) }\end{array}$ & $\begin{array}{l}\text { Sigmoidoscopy scores } \\
\text { reduced, } \\
\text { mRNA levels beta defensins } \\
2,3 \text {, and 4, upregulated in }\end{array}$ \\
\hline
\end{tabular}




\begin{tabular}{|c|c|c|c|c|}
\hline & & & & $\begin{array}{l}\text { active UC, significantly } \\
\text { reduced in treatment, } \\
\mathrm{TNF} \alpha \text { and IL1 } \alpha \text {, which } \\
\text { induce defensin expression, } \\
\text { reduced after treatment } \\
\text { Reduction of intestinal } \\
\text { Inflammation } \\
\text { regeneration of epithelial } \\
\text { tissue }\end{array}$ \\
\hline $\begin{array}{l}\text { Macfarlane et } \\
\text { al. } 2005 \text {. }\end{array}$ & $\begin{array}{l}\text { SYN: } \\
\text { B.longum combined with } \\
\text { FOS-enriched inulin - } \\
\text { Synergy } 1\end{array}$ & $\mathrm{RCT} \mathrm{n}=18,1 \mathrm{mo}$ & $\begin{array}{l}\text { Adults/ IBD } \\
\text { (UC) }\end{array}$ & $\begin{array}{l}\text { Increased bifidobacteria in } \\
\text { rectal mucosa, } \\
\text { Significant reductions in the } \\
\text { expression of molecules that } \\
\text { control inflammation in } \\
\text { active UC: TNF } \alpha \text { and IL-1a, } \\
\text { that induce defensin } \\
\text { expression, were reduced }\end{array}$ \\
\hline $\begin{array}{l}\text { Lindsay et al. } \\
2006 \text {. }\end{array}$ & FOS/Inulin $(7 / 3,15 \mathrm{~g} / \mathrm{d})$ & $3 \mathrm{wk}, \mathrm{n}=10$ & $\begin{array}{l}\text { Adults/IBD } \\
\text { (CD) }\end{array}$ & $\begin{array}{l}\text { Lower disease activity } \\
\text { scores }\end{array}$ \\
\hline $\begin{array}{l}\text { Casellas et al. } \\
2007 \text {. }\end{array}$ & FOS/Inulin $(1 / 1,12 \mathrm{~g} / \mathrm{d})$ & RCT, DB, parallel, $2 \mathrm{wk}, \mathrm{n}=19$ & $\begin{array}{l}\text { Adults/IBD } \\
\text { (UC) }\end{array}$ & $\begin{array}{l}\text { Lower disease activity, no } \\
\text { difference with placebo. } \\
\text { Lower fecal calprotectin }\end{array}$ \\
\hline $\begin{array}{l}\text { Paineau et al. } \\
2008 \text {,Chermesh } \\
\text { et al. } 2007 \text {. }\end{array}$ & $\begin{array}{l}\text { SYN 2000: cocktail } \\
\text { containing } 4 \text { probiotic } \\
\text { species and } 4 \text { prebiotics }\end{array}$ & $\mathrm{MC}, \mathrm{RCT}, \mathrm{n}=30$ & $\begin{array}{l}\text { Adults/ IBD } \\
\text { (CD) }\end{array}$ & $\begin{array}{l}\text { No effect on postoperative } \\
\text { recurrence }\end{array}$ \\
\hline
\end{tabular}

Abbreviations: FOS - Fructooligosaccharides, IL - Interleukin, SYN - Synbiotic, RCT - Randomized controlled trial, DB - Double blind, CO - Cross over, IBS - Irritable bowel syndrome, IBD - Inflammatory bowel disease, UC - Ulcerative colitis CD - Crohn's disease, mRNA - Messenger ribonucleic acid, TNF - Tumor necrosis factor. 
Table 5. Inulin-type fructan effects in experimental animal models for allergy, diabetes, and immunization.

\begin{tabular}{|c|c|c|c|c|}
\hline REF. & $\begin{array}{l}\text { Fructans used } \\
\text { (concentration) }\end{array}$ & $\begin{array}{c}\text { Study design, } \\
\text { duration, number of } \\
\text { subjects }\end{array}$ & $\begin{array}{c}\text { Target } \\
\text { group / } \\
\text { Condition }\end{array}$ & Results \\
\hline $\begin{array}{l}\text { Buddington } \\
\text { et al. } 2002 \text {. }\end{array}$ & $10 \%$ OF or inulin & $\begin{array}{l}\text { 45d trial. Exposure to } \\
\text { Candida albicans } \\
\text { (enterically), or } \\
\text { Listeria } \\
\text { monocytogenes or } \\
\text { Salmonella } \\
\text { typhimurium. N=25 } \\
\text { per group. }\end{array}$ & $\begin{array}{l}\text { Mice } \\
\text { 1,2- } \\
\text { dimethylhydr } \\
\text { azine colon } \\
\text { cancer model }\end{array}$ & $\begin{array}{l}\text { Decreased C. albicans numbers, inulin abolished } \\
\text { mortality upon Listeria infection, mortality by } \\
\text { infection of S. typhimurium was decreased compared } \\
\text { to control ( } 60 \% \text { vs } 80 \%)\end{array}$ \\
\hline $\begin{array}{l}\text { Manhart et } \\
\text { al. } 2003\end{array}$ & $10 \%$ FOS & $\begin{array}{l}\text { 16d trial, LPS } \\
\text { challenge to induce } \\
\text { endotoxemia, } n=8 \text { per } \\
\text { group }\end{array}$ & Balb/c mice & $\begin{array}{l}\text { Increased total cell yield. } \\
\text { B lymphocytes were increased in both groups. } \\
\mathrm{T} \text { lymphocytes increased in LPS-challenged mice } \\
\text { after FOS enrichment } \\
\text { The increase of CD4(+) cells was more pronounced } \\
\text { than that of CD8(+) cells, increasing the CD4:CD8 } \\
\text { ratio }\end{array}$ \\
\hline $\begin{array}{l}\text { Milo et al. } \\
2004 \text {. }\end{array}$ & Inulin (1\%) & $\begin{array}{l}\text { 1wk } \\
\text { supplementation, } \\
\text { Salmonella } \\
\text { typhimurium } \\
\text { infection at d7. Blood } \\
\text { sampling at d14. } \\
\mathrm{N}=4-6 \text { per group. }\end{array}$ & Piglets & $\begin{array}{l}\text { No effect on blood phagocyte activation level or small } \\
\text { intestinal IgA upon Salmonella typhimurium infection }\end{array}$ \\
\hline $\begin{array}{l}\text { Stillie et al. } \\
2005 \text {. }\end{array}$ & Inulin $(4,8 \%)$ & $\begin{array}{l}35 \mathrm{~d} \text { trial. } \mathrm{N}=30-38 \\
\text { per dietary group. }\end{array}$ & $\begin{array}{l}\text { Diabetes } \\
\text { prone } \\
\text { /resistant rats }\end{array}$ & $\begin{array}{l}\text { In diabetes prone rats: higher level of B cells in PP, } \\
\text { higher number of IgA+ cells in jejunum. In diabetes } \\
\text { resistant rats: higher level of CD } 8+\text { lymphocytes in } \\
\text { PP. Both types: lower number of splenocytes, } \\
\text { decreased production of IL- } 4 \text { and increased } \\
\text { production of IL-10 by stimulated spleen cells, no } \\
\text { effect on production of IFN- } \gamma \text { or TGF- } \beta \text { by }\end{array}$ \\
\hline
\end{tabular}


Critical Reviews in Food Science and Nutrition

\begin{tabular}{|c|c|c|c|c|}
\hline & & & & splenocytes or MLN cells \\
\hline $\begin{array}{l}\text { Vos et al. } \\
2006 \text {. }\end{array}$ & $\begin{array}{l}\text { OF/inulin }(1 / 1,1- \\
10 \%)\end{array}$ & $\begin{array}{l}\text { Influenza vaccination } \\
\text { model, } \mathrm{n}=10 \text { per } \\
\text { group. Trial of } 31 \mathrm{~d} \text {. } \\
\text { Dietary intervention } \\
\text { of } 14 \mathrm{~d} \text { and } 20 \mathrm{~d} \text {. }\end{array}$ & $\begin{array}{l}\text { Mice } \\
\text { Influenza } \\
\text { vaccination } \\
\text { study }\end{array}$ & $\begin{array}{l}\text { Increased DTH response to influenza vaccine. No } \\
\text { effect on vaccine specific serum IgG. No effect on } \\
\text { DTH response with inulin/OF, OF or inulin }\end{array}$ \\
\hline $\begin{array}{l}\text { Adogony et } \\
\text { al. } 2007 \text {. }\end{array}$ & scFOS (nd) & $\begin{array}{l}\text { Supplementation to } \\
\text { the mother from d35 } \\
\text { of gestation to } \\
\text { weaning, (n=16), } \\
\text { vaccination of pups. }\end{array}$ & Dogs & $\begin{array}{l}\text { Mammary secretions in dogs increased in IgM content } \\
\text { (no effect on IgG1, IgG2 and IgA) and concomittantly } \\
\text { increased IgM immune response to vaccination of } \\
\text { pups }\end{array}$ \\
\hline $\begin{array}{l}\text { Fujitani et } \\
\text { al. } 2007 \text {. }\end{array}$ & $5 \% \mathrm{FOS}$ & $\begin{array}{l}\text { Effect on food } \\
\text { allergy, } 8 \text { wk. } \mathrm{N}=10 \\
\text { OVA nonsensitized, } \\
\text { n=6 OVA sensitized, } \\
\mathrm{n}=7 \text { OVA sensitized } \\
+ \text { FOS diet. }\end{array}$ & Nc/jic mice & $\begin{array}{l}\text { Reduced number of CCR4+cells, mast cells and } \\
\text { edema formation rate in the duodenum (antiallergic } \\
\text { activity for food allergy) }\end{array}$ \\
\hline $\begin{array}{l}\text { Vos et al. } \\
\text { 2007a. }\end{array}$ & $\begin{array}{l}\text { 1-5\% (w/w) acidic } \\
\text { oligosaccharides } \\
\text { (AOS), } \\
\text { combinations of } \\
\text { AOS and 9/1 LC } \\
\text { GOS/FOS }\end{array}$ & $\begin{array}{l}6 \mathrm{wk}, \text { vaccination } \\
\text { trial, } \mathrm{n}=10 \text { per group }\end{array}$ & $\begin{array}{l}\text { Mice } \\
\text { Influenza } \\
\text { vaccination } \\
\text { study }\end{array}$ & $\begin{array}{l}\text { AOS enhanced vaccine-specific DTH responses and } \\
\text { reduced in T-helper2 (Th2) cytokine production by } \\
\text { splenocytes in vitro. (systemic immune response was } \\
\text { Th1-skewed). } \\
\text { GOS/FOS and AOS were more effective in enhancing } \\
\text { DTH responses than either of the oligosaccharides } \\
\text { alone }\end{array}$ \\
\hline $\begin{array}{l}\text { Barrat et al. } \\
2008 \text {. }\end{array}$ & $\begin{array}{l}\text { GOS/inulin, } \\
88 / 12 ; 5.6 \mathrm{~g} / \mathrm{L}\end{array}$ & $\begin{array}{l}\text { 40d trial, } 14 \mathrm{~d} \\
\text { formula } \\
\text { supplemented with } \\
\text { prebiotics. D18: } \mathrm{n}= \\
20 \quad \text { CTL, } \mathrm{n}=22 \\
\text { GOS/inulin and } \mathrm{n}=7\end{array}$ & Rats & $\begin{array}{l}\text { Most parameters unaltered but increased bacterial } \\
\text { translocation (BT) toward spleen }\end{array}$ \\
\hline
\end{tabular}




\section{Critical Reviews in Food Science and Nutrition}

\begin{tabular}{|c|c|c|c|c|}
\hline & & $\begin{array}{l}\text { mother-reared } \\
\text { rats; } d 40: n=14 \text { CTL } \\
\text { and GOS/inulin) }\end{array}$ & & \\
\hline $\begin{array}{l}\text { Benyacoub } \\
\text { et al. } 2008 .\end{array}$ & $5 \%$ FOS:inulin & $\begin{array}{l}\text { Salmonella } \\
\text { typhimurium } \\
\text { infection, } \mathrm{n}=20 \text { per } \\
\text { group. Trial of } 5 \mathrm{wk} \text {, } \\
1 \text { wk of dietary } \\
\text { intervention before } \\
\text { immunization. }\end{array}$ & Balb/c mice & $\begin{array}{l}\text { Specific Salmonella serum IgG and fecal IgA } \\
\text { significantly increased } \\
\text { Peritoneal macrophage phagocytic activity increased } \\
\text { Production of IFN } \gamma \text {, IL-12, and TNF- } \alpha \text { increased in } \\
\text { spleen upon stimulation } \\
\text { Survival rate upon challenge with virulent Salmonella } \\
\text { improved }\end{array}$ \\
\hline $\begin{array}{l}\text { Schouten et } \\
\text { al. } 2009 .\end{array}$ & $\begin{array}{l}\text { GOS/lc inulin } \\
(9 / 1,2 \%)\end{array}$ & $\begin{array}{l}\text { Allergic model, } \mathrm{n}=6 \\
\text { per group. Dietary } \\
\text { intervention } 2 \mathrm{wk} \\
\text { prior to sensitization } \\
\text { and during trial } \\
\text { duration of } 8 \mathrm{wk}\end{array}$ & $\begin{array}{l}\text { Mice } \\
\text { Whey } \\
\text { sensitization } \\
\text { protocol }\end{array}$ & $\begin{array}{l}\text { Prebiotics or probiotic B. breve alone were less } \\
\text { effective for reducing anaphylactic reaction as } \\
\text { compared to the combination; allergic skin response } \\
\text { reduced with prebiotics; further enhancement by B. } \\
\text { breve. Acute allergic skin reaction is diminished+; } \\
\text { whey specific Treg cells may be involved }\end{array}$ \\
\hline
\end{tabular}

Abbreviations: FOS - Fructooligosaccharides, Ig - Immunoglobulin, OF - Oligofructose, PP - Peyer's patches, IL Interleukin, IFN - Interferon, SYN - Synbiotic, MLN - Mesenteric lymph nodes, Sc - Short chain, GOS Galactooligosaccharides, TGF - Transforming growth factor, TNF - Tumor necrosis factor, LPS Lipopolysaccharide, DTH - Delayed type hypersensitivity, OVA - Ovalbumin, CCR4 - C-C chemokine receptor type 4, AOS - Acidic oligosaccharides, Lc - Long chain, Th - T helper. 
Table 6. Inulin-type fructan induced immune effects in infants, adults, and elderly, burn patients, and pregnant women.

\begin{tabular}{|c|c|c|c|c|}
\hline REF. & $\begin{array}{l}\text { Fructans used } \\
\text { (concentration) }\end{array}$ & $\begin{array}{l}\text { Study design, } \\
\text { duration, number of } \\
\text { subjects }\end{array}$ & $\begin{array}{l}\text { Target group / } \\
\text { Condition }\end{array}$ & Results \\
\hline \multicolumn{5}{|c|}{ Studies in infants: } \\
\hline $\begin{array}{l}\text { Saavedra and } \\
\text { Tschernia. } \\
2002 \text {. }\end{array}$ & $\begin{array}{l}\text { OF/inulin }(7 / 3,0,2 \\
\mathrm{g} / \mathrm{kg} \mathrm{BW} / \mathrm{d})\end{array}$ & $\begin{array}{l}\text { RCT, DB, } 10 \mathrm{wk}, \\
\mathrm{n}=55\end{array}$ & Infants (7-9mo) & $\begin{array}{l}\text { Higher blood IgG levels after measles } \\
\text { vaccination }\end{array}$ \\
\hline $\begin{array}{l}\text { Duggan et al. } \\
2003 \text {. }\end{array}$ & $\mathrm{OF}(0,7 \mathrm{~g} / \mathrm{d})$ & $\mathrm{RCT}, 6 \mathrm{mo}, \mathrm{n}=282$ & Infants $(6-12 \mathrm{mo})$ & $\begin{array}{l}\text { No effect on antibody response after } \\
\text { vaccination with } H \text {. influenza type B } \\
\text { vaccine }\end{array}$ \\
\hline $\begin{array}{l}\text { Bakker- } \\
\text { Zierikzee et al. } \\
2006 .\end{array}$ & $\begin{array}{l}\text { GOS/inulin }(9 / 1 \\
0,6 \mathrm{~g} / \mathrm{dl} \text { formula })\end{array}$ & $\begin{array}{l}\text { RCT, DB, parallel, } \\
32 \mathrm{wk}, \mathrm{n}=57\end{array}$ & Infants (3d) & $\begin{array}{l}\text { Higher fecal IgA (no effect of probiotic } \\
\text { B.animalis) }\end{array}$ \\
\hline $\begin{array}{l}\text { Moro et al. } \\
2006 \mathrm{a}\end{array}$ & $\begin{array}{l}\text { GOS/lc inulin } 9 / 1 \text {, } \\
0.8 \mathrm{~g} / 100 \mathrm{ml} \\
\text { formula }\end{array}$ & $\begin{array}{l}\text { RCT, DB, parallel, } 6 \\
\text { mo, } n=242\end{array}$ & $\begin{array}{l}\text { Infants at risk for } \\
\text { atopy }\end{array}$ & $\begin{array}{l}\text { Decreased incidence of development of } \\
\text { atopic dermatitis, no change in severity }\end{array}$ \\
\hline $\begin{array}{l}\text { Arslanoglu et } \\
\text { al. } \\
2008, \text { Arslanog } \\
\text { lu et al. } 2007\end{array}$ & $\begin{array}{l}\mathrm{g} / \mathrm{L} \\
\mathrm{scGOS} / \mathrm{lcFOS}\end{array}$ & $\mathrm{RCT}, \mathrm{DB}, \mathrm{n}=152$ & $\begin{array}{l}\text { Healthy term infants } \\
\text { up to } 2 \text { yrs }\end{array}$ & $\begin{array}{l}\text { Lower incidence of allergic } \\
\text { manifestations, incidences for AD, } \\
\text { recurrent wheezing, and allergic urticaria, } \\
\text { upper respiratory tract infections, fever } \\
\text { episodes, antibiotic prescriptions, effect } \\
\text { lasting beyond the intervention period }\end{array}$ \\
\hline $\begin{array}{l}\text { Scholtens et } \\
\text { al. } 2008 .\end{array}$ & $\begin{array}{l}\text { GOS/inulin }(9 / 1 \\
0,6 \mathrm{~g} / \mathrm{dl} \text { formula })\end{array}$ & $\begin{array}{l}\text { RCT, DB, } 26 \text { wk, } \\
n=187\end{array}$ & Term infants & Higher fecal sIgA levels \\
\hline $\begin{array}{l}\text { van Hoffen et } \\
\text { al. } 2009 \text {. }\end{array}$ & $\begin{array}{l}8 \mathrm{~g} / 1 \text { GOS/FOS } \\
9 / 1 \\
\text { (IMMUNOFORTI } \\
\mathrm{S})\end{array}$ & $\begin{array}{l}\text { Children were } \\
\text { vaccinated with } \\
\text { Hexavac against a.o. } \\
\text { DTP. }\end{array}$ & $\begin{array}{l}\text { Healthy infants (3 } \\
\text { mo) }\end{array}$ & $\begin{array}{l}\text { Significant reduction in plasma total IgE, } \\
\text { IgG1, IgG2 and IgG3, } \\
\text { no effect on IgG4. } \\
\text { CMP-specific IgG1 significantly } \\
\text { decreased. } \\
\text { DTP-specific Ig levels not affected. }\end{array}$ \\
\hline
\end{tabular}


Critical Reviews in Food Science and Nutrition

\begin{tabular}{|c|c|c|c|c|}
\hline $\begin{array}{l}\text { Perez et al. } \\
2010 \text {. }\end{array}$ & $\begin{array}{l}\text { L.acidophilus, } \\
\text { FOS and inulin }\end{array}$ & DB,PCT, n=162 & $\begin{array}{l}\text { Children with a high } \\
\text { index of natural } \\
\text { exposure to } \\
\text { microorganisms }\end{array}$ & $\begin{array}{l}\text { Rate of Ig and isoagglutinin acquisition } \\
\text { was similar in both groups. } \\
\text { No difference between groups in antibody } \\
\text { levels neither before nor after vaccination. } \\
\text { Days of fever and number of episodes of } \\
\text { infection were not statistically different in } \\
\text { either group }\end{array}$ \\
\hline $\begin{array}{l}\text { Raes et al. } \\
2010 .\end{array}$ & $\begin{array}{l}\text { scGOS/lcFOS, } \\
\text { ratio } 9: 1\end{array}$ & $26 \mathrm{wk}, \mathrm{n}=215$ & Term infants & No changes observed \\
\hline \multicolumn{5}{|c|}{ Studies in elderly people: } \\
\hline $\begin{array}{l}\text { Bunout et al. } \\
2002 \text {. }\end{array}$ & $\begin{array}{l}\text { OF/inulin } \\
(70 / 30 \%, 6 \mathrm{~g} / \mathrm{d})\end{array}$ & $\begin{array}{l}\text { RCT, parallel, } 28 \mathrm{wk}, \\
\mathrm{n}=66\end{array}$ & Elderly $>70 y$ & $\begin{array}{l}\text { No difference between groups for antibody } \\
\text { response to influenza and S. pneumoniae } \\
\text { vaccination }\end{array}$ \\
\hline $\begin{array}{l}\text { Guigoz et al. } \\
2002 \text {. }\end{array}$ & FOS $8 \mathrm{~g} / \mathrm{d} 2 \times 4$ & $\mathrm{~N}=19$ & Elderly people & $\begin{array}{l}\text { Decreased phagocytic activity of } \\
\text { granulocytes and monocytes, as well as a } \\
\text { decreased expression of interleukin-6 } \\
\text { mRNA in peripheral blood monocytes }\end{array}$ \\
\hline $\begin{array}{l}\text { Langkamp- } \\
\text { Henken et al. } \\
2004 \text {. }\end{array}$ & $\begin{array}{l}240 \mathrm{~mL} / \mathrm{d} \text { FOS } \\
\text { from sucrose }\end{array}$ & $\begin{array}{l}\mathrm{P}, \mathrm{RCT}, \mathrm{DB}, 5 \mathrm{mo}, \\
\mathrm{n}=157\end{array}$ & $\begin{array}{l}\text { Elderly people } \\
>65 y\end{array}$ & $\begin{array}{l}\text { Enhanced immune function indicated by } \\
\text { increased influenza vaccine response and } \\
\text { lymphocyte activation, less fever, fewer } \\
\text { antibiotics }\end{array}$ \\
\hline $\begin{array}{l}\text { Langkamp- } \\
\text { Henken et al. } \\
2006 .\end{array}$ & $\begin{array}{l}8 \mathrm{oz} / \mathrm{d} \text { of an } \\
\text { experimental } \\
\text { formula containing } \\
\text { antioxidants, zinc, } \\
\text { selenium, } \\
\text { fermentable } \\
\text { oligosaccharides, } \\
\text { and structured } \\
\text { triacylglycerol or } \\
\text { an isoenergetic, } \\
\text { isonitrogenous } \\
\text { control formula }\end{array}$ & $\begin{array}{l}\text { Prospective RCT } \\
\text { DB, } 183 d, n=66\end{array}$ & $\begin{array}{l}\text { Free living } \\
\text { elderly }>65 y\end{array}$ & $\begin{array}{l}\text { Enhanced immune function and fewer } \\
\text { days of URTI symptoms }\end{array}$ \\
\hline
\end{tabular}


Critical Reviews in Food Science and Nutrition

\begin{tabular}{|c|c|c|c|c|}
\hline $\begin{array}{l}\text { Schiffrin et al. } \\
2007 \text {. }\end{array}$ & $1.3 \mathrm{~g} / 250 \mathrm{ml} \mathrm{FOS}$ & $\begin{array}{l}\text { P,RCT,DB, } n=74,12 \\
\text { wk }\end{array}$ & Elderly people $>70 \mathrm{y}$ & $\begin{array}{l}\text { Specific mRNA extracted from blood } \\
\text { leucocytes: TNF- } \alpha \text { mRNA and IL- } 6 \\
\text { mRNA diminished. } \\
\text { Serum sCD14, a product shed by } \\
\text { activated macrophages, decrease. } \\
\text { No significant differences were detected in } \\
\text { the fecal gut flora or nutritional } \\
\text { parameters. }\end{array}$ \\
\hline $\begin{array}{l}\text { Vulevic et al. } \\
2008 .\end{array}$ & B-GOS $5,5 \mathrm{~g} / \mathrm{d}$ & $\begin{array}{l}\text { DB, PCT, CO, n=44, } \\
24 \text { wk }\end{array}$ & $\begin{array}{l}\text { Healthy elderly } \\
\text { people }\end{array}$ & $\begin{array}{l}\text { Significant increases in phagocytosis, NK } \\
\text { cell activity, and the production of IL-10, } \\
\text { and significant reduction in production of } \\
\text { IL-6, IL-1beta, and TNF- } \alpha\end{array}$ \\
\hline $\begin{array}{l}\text { Amati et al. } \\
2010 .\end{array}$ & $\begin{array}{l}\text { SYN: LGG and } \\
\text { OF }\end{array}$ & $1 \mathrm{mo}, \mathrm{N}=10$ & Elderly people & $\begin{array}{l}\text { Increase age-depressed values of IL-1, IL- } \\
6 \text { and IL- } 8 \text { with a trend to a modest } \\
\text { increase for the restant cytokines }\end{array}$ \\
\hline \multicolumn{5}{|c|}{ Studies in pregnant women and burn patients: } \\
\hline $\begin{array}{l}\text { Shadid et al. } \\
2007 .\end{array}$ & $\begin{array}{l}3 \text { times/d with } 3 \mathrm{~g} \\
\text { GOS/lcFOS (at a } \\
\text { ratio of 9:1) }\end{array}$ & $\begin{array}{l}\text { RCT, DB, PC, } \mathrm{n}=48 . \\
\text { From week } 25 \text { of } \\
\text { gestation until } \\
\text { delivery }\end{array}$ & Pregnant women & $\begin{array}{l}\text { Fetal immune parameters did not differ } \\
\text { significantly }\end{array}$ \\
\hline $\begin{array}{l}\text { Olguin et al. } \\
2005 .\end{array}$ & OF $6 g / d$ & $\begin{array}{l}\text { RCT, DB, } n=41,15 \\
\text { d }\end{array}$ & Burn patients & $\begin{array}{l}\text { Normalization of gastrointestinal } \\
\text { permeability is not accelerated by prebiotic } \\
\text { intake }\end{array}$ \\
\hline \multicolumn{5}{|c|}{ Studies in healthy adult males: } \\
\hline $\begin{array}{l}\text { Seidel et al. } \\
2007 \text {. }\end{array}$ & Inulin $(9 \mathrm{~g} / \mathrm{d})$ & $\begin{array}{l}\text { RCT, DB, parallel, } \\
5 \mathrm{wk}, \mathrm{n}=38\end{array}$ & Adult males & $\begin{array}{l}4 \text { of } 23 \text { immunological parameters } \\
\text { investigated were affected }\end{array}$ \\
\hline
\end{tabular}

Abbreviations: FOS - Fructooligosaccharides, Ig - Immunoglobulin, OF - Oligofructose, IL - Interleukin, SYN Synbiotic, NK - Natural killer, Sc - Short chain, LGG - Lactobacillus rhamnosus GG, P or PC - Placebo controlled, RCT - Randomized controlled trial, DB - Double blind, GOS - Galactooligosaccharides, CO - Cross over, mRNA Messenger ribonucleic acid, TNF - Tumor necrosis factor, Lc - Long chain, BW - Body weight, AD - Atopic dermatitis, DTP - Diphteria, tetanus, polio, CMP - Cow's milk protein, URTI - Upper respiratory tract infections. 


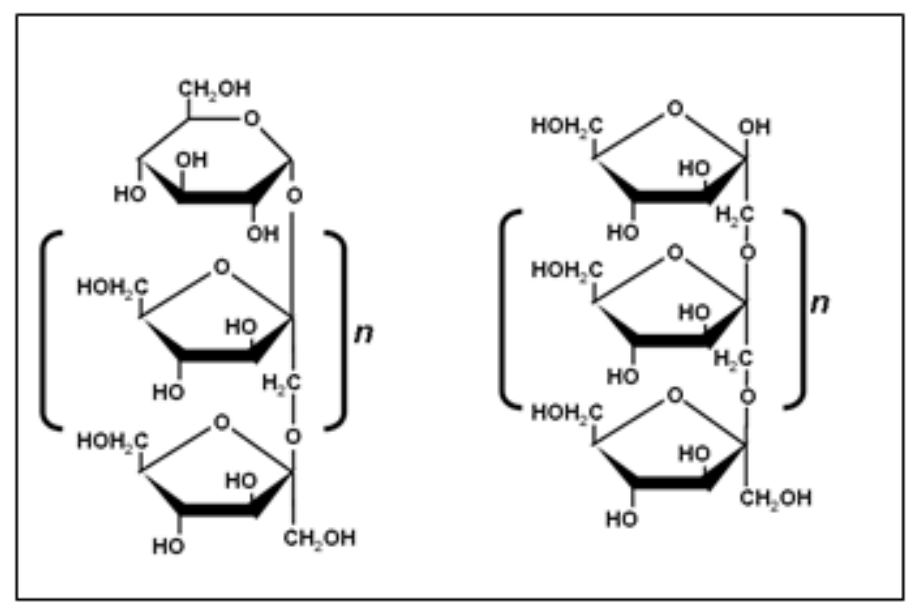

Figure 1. Haworth projections of fructan molecules. Left projection depicts an inulin type fructan of the GFn type, right projection depicts an inulin-type fructan of the Fn type. 


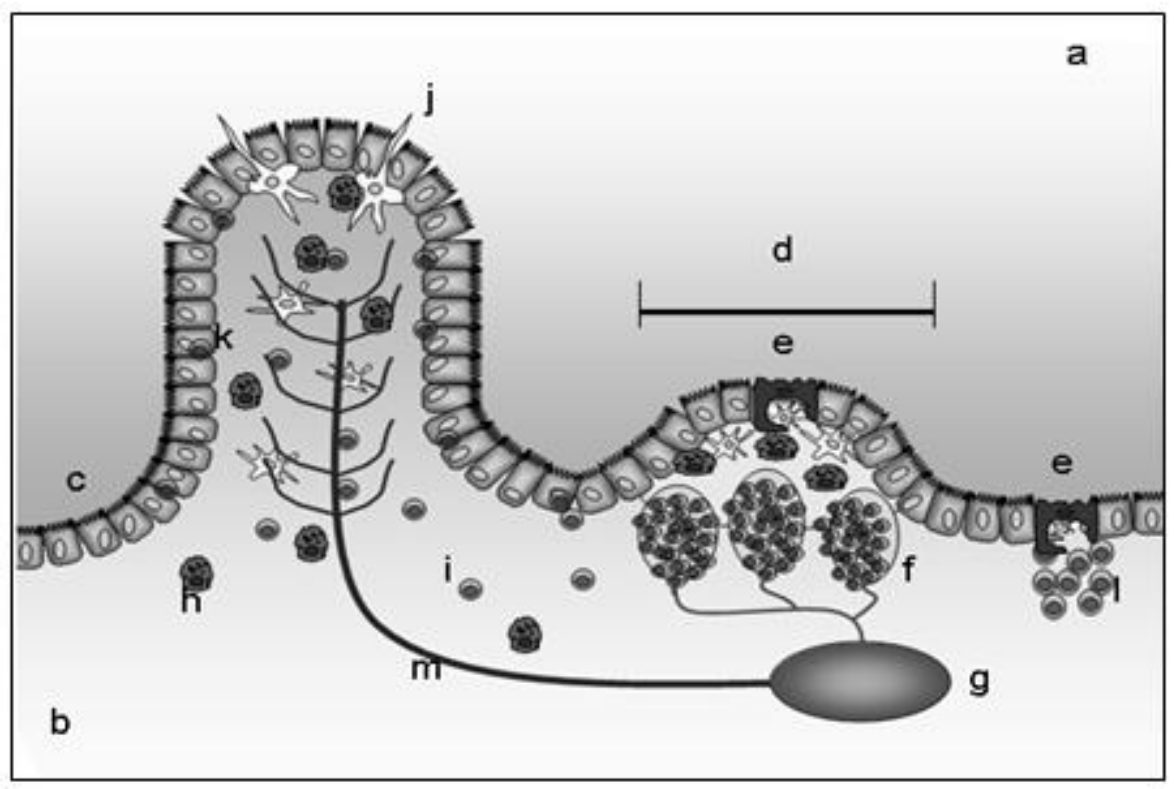

Figure 2. Gut Associated Lymphoid Tissue (GALT). Schematic representation of the GALT structure; a) Gut lumen. b) Lamina propria. c) Enterocyte lining. d) Peyer's patch. e) Microfold cell. f) Follicle with B and T lymphocytes. g) Mesenteric lymph node. h) Lamina propria mast cell. i) Lamina propria lymphocyte. j) Dendritic cell penetrating enterocyte monolayer and sampling gut lumen. k) Intraepithelial lymphocyte. 1) lymphoid aggregates. m) High endothelial vessel [246]. N.B. Structural proportions were altered for illustrative purposes. 


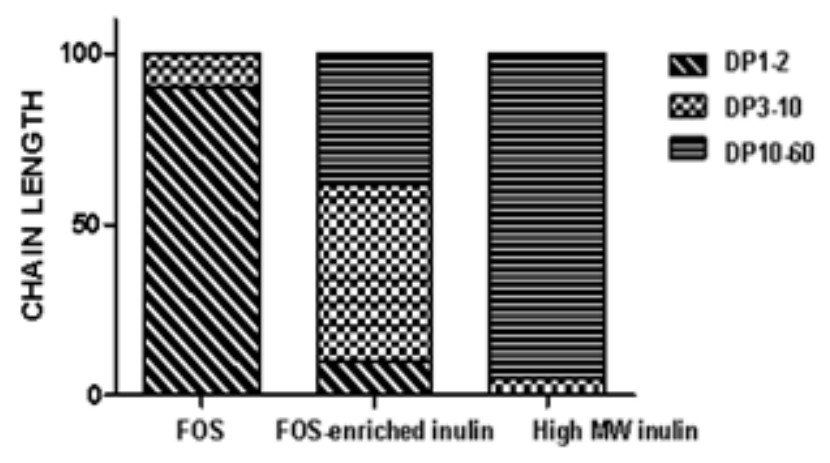

Figure 3. Chain length distribution examples of inulin-type fructans for FOS, FOS enriched inulin, and high average molecular weight inulin. 